\title{
Effects of Water Velocity on Activity of Juvenile Striped Bass
}

\author{
R. R. Bowles \\ J. S. Griffith \\ C. C. Coutant
}




\section{DISCLAIMER}

This report was prepared as an account of work sponsored by an agency of the United States Government. Neither the United States Government nor any agency Thereof, nor any of their employees, makes any warranty, express or implied, or assumes any legal liability or responsibility for the accuracy, completeness, or usefulness of any information, apparatus, product, or process disclosed, or represents that its use would not infringe privately owned rights. Reference herein to any specific commercial product, process, or service by trade name, trademark, manufacturer, or otherwise does not necessarily constitute or imply its endorsement, recommendation, or favoring by the United States Government or any agency thereof. The views and opinions of authors expressed herein do not necessarily state or reflect those of the United States Government or any agency thereof. 


\section{DISCLAIMER}

Portions of this document may be illegible in electronic image products. Images are produced from the best available original document. 
Printed in the United States of America. Available from National Technical Information Service

U.S. Department of Commerce

5285 Port Royal Road, Springfield, Virginia 22161

Price: Printed Copy \$5.00; Microfiche $\$ 2.25$

This report was prepared as an account of work sponsored by the United States Government. Neither the United States nor the Energy Research and Development Administration/United States Nuclear Regulatory Commission, nor any of their employees, nor any of their contractors, subcontractors, or their employees, makes any warranty, express or implied, or assumes any legal liability or responsibility for the accuracy, completeness or usefulness of any information, apparatus, product or process disclosed, or represents that its use would not infringe privately owned rights. 
Contract No. W-7405-eng-26

EFFECTS OF WATER VELOCITY ON

ACTIVITY OF JUVENILE STRIPED BASS

R. R. Bowles, J. S. Griffith, and C. C. Coutant

ENVIRONMENTAL SCIENCES DIVISION

Publication No. 860

JULY 1976

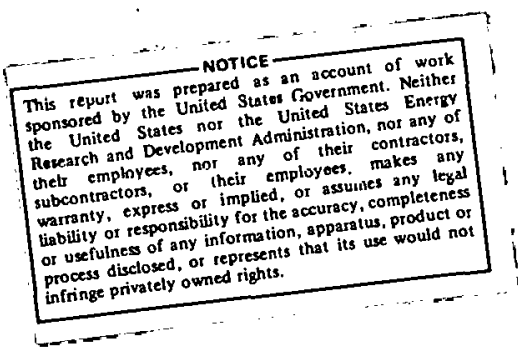

OAK RIDGE NATIONAL LABORATORY

Oak Ridge, Tennessee $\mathbf{3 7 8 3 0}$

operated by

UNION CARBIDE CORPORATION

for the

ENERGY RESEARCH AND DEVELOPMENT ADMINISTRATION 
THIS PAGE

\section{WAS INTENTIONALLY LEFT BLANK}




\section{ACKNOWLEDGEMENTS}

Special gratitude is expressed to Dr. D. A. Etnier for sharing the beauty and diversity of the regional fish fauna and for guidance during the author's graduate career. Appreciation is also expressed to $\mathrm{Dr}$. R. A. Minear for his interest and insight. Warm appreciation is expressed to Philip S. Pagoria for technical aid and encouragement. 
THIS PAGE

WAS INTENTIONALLY

LEFT BLANK 


\section{ABSTRACT}

BOWLES, Rebecca R., C. C. COUTANT, and J. S. GRIFFITH. 1976. Effects of water velocity on activity of juvenile striped bass. ORNL/TM-5368. Oak Ridge National Laboratory, Oak Ridge, Tenn. 71 pp.

The swimming activity of juvenile striped bass (Morone saxatilis Walbaum) 8 to $80 \mathrm{~mm}$ long was investigated in a test chamber simulating, on a small scale, a fixed-screen cooling water intake structure. As water velocity increased from 0 to $30 \mathrm{~cm} / \mathrm{sec}$ area and distance traveled by juvenile bass 10 to $80 \mathrm{~mm}$ long decreased. However, as water velocity increased from 0 to $3 \mathrm{~cm} / \mathrm{sec}$ area and distance covered by larval bass increased. The presence of food increased the activity of larval bass, but decreased the activity of juveniles. Area ranged by striped bass at test velocities ranging from 0 to $30 \mathrm{~cm} / \mathrm{sec}$ increased in proportion to body length. Juvenile striped bass tested at acclimation temperatures between 20 and $5 \mathrm{C}$ experienced a $30 \%$ reduction of activity. Activity was also reduced as temperature increased from 20 to $30 \mathrm{C}$. 


\section{THIS PAGE}

\section{WAS INTENTIONALLY \\ LEFT BLANK}


TABLE OF CONTENTS

Chapter

Page

I INTRODUCTION

II RELATED LITERATURE

Intake Siting and Engineering Design

Physiology of Swimming Fish

Behavioral Responses in $\mathrm{Fish}$

III STATEMENT OF THE PROBLEM

Assumptions

IV METHODS AND MATERIALS

Larval Striped Bass Observations

Juvenile I Striped Bass Observations

Juveline II Striped Bass Observations.

V RESULTS

31

Results of Larval Striped Bass Observations Results of Juvenile I Striped Bass observations Results of Juvenile II Striped Bass Observations

VI DISCUSSION

VII CONCLUSIONS 


\section{LIST OF TABLES}

Table

Page

1. Analysis of variance showing the effect of water velocity and the presence of food on area traveled by larval striped bass during 1 -min observation periods.

2. Analysis of variance showing the effect of water velocity and the presence/absence of food on distance traveled by larval stipred bass during 1 -min observation periods.

3. Analysis of variance showing the effect of fish size, water velocity, and presence/ absence of food on the area traveled by juvenile striped bass 10 to $50 \mathrm{~mm}$ long during 3-min observation periods.

4. Analysis of variance showing the effect of temperature, water velocity, and duration of the experiment on area ranged by juvenile striped bass $80 \mathrm{~mm}$ long.

5. Analysis of variance showing the effect of temperature, water velocity, and duration of the experiment on distance traveled by juvenile striped bass $80 \mathrm{~mm}$ long. 
LIST OF FIGURES

Figure

Page

1. A numbered background grid was used to monitor the activity of larval striped bass.

2. Tank modifications included portholes, a circular partition, baffles, and a test chamber with a numbered grid on the bottom for monitoring fish activity.

3. The 1-min activity pattern of a $25 \mathrm{~mm}$ juvenile striped bass at a water velocity of $15 \mathrm{~cm} / \mathrm{sec}$ is superimposed on a replicate of the grid pattern used to monitor activity of juvenile bass 10 to $50 \mathrm{~mm}$ long.

4. The background grid pattern for monitoring activity of $80 \mathrm{~mm}$ juvenile striped bass.

5. Distance traveled (A) and area ranged (B) by larval striped bass at two velocities during 1 -min activity periods.

6. Area and distance traveled by larval striped bass at $0 \mathrm{~cm} / \mathrm{sec}$ and $3 \mathrm{~cm} / \mathrm{sec}$ with and without food present.

7. Area traveled during a 3-min observation period as a function of the number of $25 \mathrm{~mm}$ juvenile striped bass present in the test chamber.

8. The effect of increasing velocity on juvenile striped bass mobility in the presence and absence of food.

9. The relationship of water velnrit.y and distance between fish for 3 sizes of juvenile striped bass.

10. Mean percentage of the 3-min observation spent in positive (P), negative (N), or lateral (L) rheotaxis at the various test velocities.

11. Area ranged (A) and distance, traveled (B) by $80 \mathrm{~mm}$ striped bass at four water velocities.

12. Thermal effects on distance traveled by $80 \mathrm{~mm}$ juvenile striped bass. 
13. Thermal effects on area ranged by $80 \mathrm{~mm}$ striped bass.

14. Effects of length of time fish had been swimming on area ranged (A) and distance traveled (B) by $80 \mathrm{~mm}$ juvenile striped bass.

15. Area ranged by blind and sighted juvenile striped bass during activity periods at $20 \mathrm{C}$ and water velocities of $15 \mathrm{~cm} / \mathrm{sec}$ (A) and 30 $\mathrm{cm} / \mathrm{sec}$ (B)

16. Area ranged by $80 \mathrm{~mm}$ juvenile striped bass with or without an eddy current at $15 \mathrm{C}$ during 1-min activity periods.

17. Relationship of rheotaxis to water velocities and temperatures tested. 


\section{CHAPTER I}

\section{INTRODUCTION}

An increasing energy demand has led to the construction and expansion of a large number of power plants. At present, steam electric power generation annually requires 227 trillion/yr (60 trillion gal/yr) or approximately 15\% of the total.river and stream flow in the United States (USEPA, 1973a). Interactions between aquatic organismș and power plants represent an area of growing environmental concern.

Cooling water intakes and discharges are two distinct interfaces power plants have with the aquatic ecosystem. Previous emphasis has been directed at biological damage and/or enhancement created by thermal effluents. Deficiencies in knowledge of water intake-associated biological damage have recently become apparent.

Biological damage occurring at cooling water intake structures is generally classified as entrainment, entrapment, or impingement. Aquatic organisms less than $50 \mathrm{~mm}$ long are not usually retained on intake screens and are subsequently entrained through power plant pumps and condensers. Entrapment occurs when fish are drawn with the cooling water flow into forebays, areas immediately in front of intake screens. Mortalities occur when plant condenser cooling lines are thermally or chemically back-flushed or 
when organisms, having no route of escape, swim until exhausted and fall against the intake screen. Impingement occurs when fish are unable to escape from the surface of the intake screen.

The study of environmental aspects of cooling water intake structures requires a multidisciplinary approach. Such diverse fields as engineering, physiology, and ethology contribute to the understanding and reduction of adverse intake conditions. While important contributions from other disciplines are considered, observation of fish behavior is the basis for the following investigation. 
CHAPTER II

\section{RELATED LITERATURE}

A significant percentage of fish mortality due to entrapment and impingement can be avoided by combining 1) engineering design, 2) familiarity with swimming stamina of fish at various life stages, and 3) recognition of behavioral characteristics of local fishes under a variety of physical conditions (Schuler and Larson, 1974; Bibko et al., 1974; Riesbol, 1974). Research efforts have been. stimulated by the Federal water Pollution Control Act as amended in 1972 (Public Law 92-500). In section 316 (b) the act requires that "...the location, design, construction and capabity of cooling water structures reflect the best technology available for minimizing adverse environmental impact."

Intake Siting and Engineering Design

Physical location of power plants has significant impact on the magnitude of fish mortality. Cooling water sources include lakes, rivers, oceans, and estuaries. Because estuarine environments are highly productive, substantial damage to the standing crop of many organisms is likely in these locations (Landry and Strawn, 1974). Tidal action and salinity are design problems in estuarine and near-shore ocean intakc structures. Lake sites present 
difficulties with thermal stratification. River locations may face low flow and siltation problems (USEPA, 1973b).

Location of cooling water intakes with respect to the shoreline of a given body of water may influence the amount of biological damage (Bainbridge, 1964; Sonnichsen et al., 1973). Generally, intakes located at the head of a cove or canal attract, trap, and impinge large numbers of fish. A flush-with-shoreline design is considered best technologically because it utilizes natural currents to remove fish and debris from the intake (USEPA, 1973a).

Initially the problem of exduding fish and other debris from water intakes was viewed from an engineering point-ofview. Primary considerations were physical protection of power plant condenser cooling tubes and maintenance of constant hydraulic head. (Bell, 1974). Design engineers accepted existing intake configurations as standard without consideration of site specific environmental conditions (Sonnichsen et al., 1973).

Burns (1966) described a diversity of commercial and industrial intake screen designs including revolving drum screens, link belt screens, perforated plates, and louver diverters. Several conventional screen designs were reviewed by Mayo (1974) who suggested fixed screens had on-shoreline applications where strong currents parallel to the face of the screen carried fish away from the orifice. Traveling screens of various configurations were most popular and had 
widest adaptability (Bates and Vanderwalker, 1970). Filtering systems such as rapid sand and gravel or leaky dam filters were new designs but were limited by capacity. Alternative and as yet untested methods were suggested such as an in-stream heat exchanger (Mayo, 1974). Other nonscreening methods for protection of aquatic life involved closed-loop cooling towers which reduced the total volume of water required.

Before development of self-cleaning traveling screens fish removal was accomplished by laborious, manual clearing and in the case of fixed screens even required plant shutdown (Kerr, 1953). Handling stress was added to impingement stress and mortalities were high. Early traveling screens were not equipped with baskets and incidents of reimpingement were frequent (Mayo, 1974). A basket system was developed for use with traveling or stationary screens. In fixed screen applications the leading edge of the basket scraped fish from the screen and deposited them in a fish removal flume. Basket-scrapper systems damaged as many tish as they saved (Landry and Strawn, 1974). Low pressure water jets were developed to gently remove impinged organisms and traveling screen velocities were increased to improve survival. Fish removal flumes were designed to be hydraulically smooth and permit rapid return of fish with minimum damage (Mayo, 1974). 
Schuler (1973) suggested that an array of louvers placed in front of intake screens could be useful in diverting fish. Louvers could be variously spaced and oriented at an optimum guiding angle for a particular velocity. However, as Eicher (1974) pointed out, guiding louvers lose their efficiency in low velocities. Similar information on guidance using velocity barriers or vanes showed placement of vanes does effect the path of swimming fish (Kerr, 1953).

Another intake design, called a velocity cap, has reduced fish mortality by as much as $90 \%$ below conventional designs (Weight, 1958). A velocity cap is a concrete slab placed a short distance above the inlet of an intake pipe opening vertically a few feet above the floor of a body of water. A less abrupt change in velocity is produced by reorienling the flow pattern from vertical to horizontal. However, by creating reef-like microenvironments such intakes actually attracted fish (Downs and Meddock, 1974).

Two additional engineering problems must be considered in siting and design of power plants. Area hydraulics must be favorable and fish protection measures designed must be economically feasible. Sonnichsen, et al. (1973) pointed out that ecological necessity in design may not be economically practical. Kerr (1953) demonstrated that intakeguidance systems successful at one site were frequently unsuccessful in reducing fish mortalities at other locations. Because of site specific parameters, each fish preservation 
scheme must be custom designed for'a particular application. This contributes substantially to initial engineering costs.

Physiology of Swimming Fish

One of the most critical design features with respect to the magnitude of fish mortality at power plants is the approach velocity, the rate at which water travels prior to passing through the intake screen. Many techniques have been developed to measure the swimming ability of various species of fish and in some cases swim speed data have been used to avoid lethal approach velocities. Types of apparati used to study swim speed included oval channels (Macleod, 1967), rotating circular (annular) channels (Gray, 1937; Fry and Hart, 1948; Bainbridge, 1958), and glass or steel pipe (Brett and Glass, 1973).

In an attempt to quantify the abijity of a wide variety of fish to swim at a range of velocities the following types of swim speeds were defined (King, 1970; Sonnichsen et al., 1972; Bibko et al., 1974):

1) crusing speed - mean water velocity against which a fish could swim for hours.

2) sustained speed - maximum water velocity against which a fish could swim continuously for a test period of several minutes.

3) dart, burst, or escape speed - maximum water velocity against which a fish could swim in short burst's with some forward progress from a single effort. 
Definitions of swim speeds were as varied as the experimental methods. Burst speed was quantified by Bainbridge (1958) as $V=1 / 4 \mathrm{I}(3 \mathrm{f}-4)$ where $V$ was speed in $\mathrm{cm} / \mathrm{sec}$, I was body length in $\mathrm{cm}$, and $f$ was frequency of tail beats/sec. Maximum swim speed was defined by MacLeod (1967) as the velocity at which fish could swim for at least three minutes in a current slightly exceeding their swimming ability. Bibko et al. (1974) defined impingement velocity as that necessary to bring about impingement in $30 \mathrm{sec}$. Final swimming speed (Brett et al., 1958) was the velocity which held a fish permanently against the intake screen. Critical swim speed was defined by Hocutt (1973) as the speed at which an individual can no longer actively orient to the current.

The swimming ability of fish is closely related to metabolism. Fry (1947) observed animals have a scope for activity, the energy difference remaining once the metabolic requirement for "the organism's integration" (i.e., growth, reproduction) have been subtracted from total metabolism. Temperature and dissolved oxygen are two important variables that should be considered when evaluating the swimming ability or "scope for activity" of fish at specific power plant sites (Bell, 1973).

Because fish are poikilothermic, their body temperature reflects ambient envirommental temperature. The role of water temperature in swimming performance of fish has been 
measured by Fry and Hart (1948), Keenleyside and Hoar (1954), Brett et al. (1958), Beamish (1966), and Bibko et al. (1974). Swimming performance decreased whenever water temperature varied from acclimation temperature (Brett, 1963). Larimore and Duever (1963), on the other hand, found by subjecting acclimated fish to a broad spectrum of test temperatures that fish performed best at $5 \mathrm{C}$ above acclimation. Beamish (1966) and Brett (1963) found cruising speeds were affected by temperature. Escape speeds showed little variation with respect to temperature.

Beamish (1964) showed fish exhibit a $60 \%$ reduction in swimming ability when dissolved oxygen (D.O.) was reduced to a third of the saturation value. Decreased oxygen effects various species differently. Swim speeds of juvenile largemouth bass, Micropterus salmoides, were independent of dissolved oxygen above $6 \mathrm{mg} / 1$ at $25 \mathrm{C}$, but swim speeds were reduced when D.O. fell to $5 \mathrm{mg} / 1$. Coho salmon, Oncorhynchus kisutch, lost speed if oxygen fell below $9 \mathrm{mg} / \mathrm{l}$ (Dahlberg et al., 1968).

For larval and juvenile fish, swimming endurance varies inversely as the velocity and directly with respect to size of the fish (Bainbridge, 1958; Dahlberg et al., 1968; Bihkn, 1974; and Skinner, 1974). When size data was converted to body lengths, Brett (1965) found smaller fish have higher swimming speeds. 
Mortality caused by entrainment may be due to shear stress, thermal shock, chemical, or pressure stress (Coutant, 1974). Impingement mortality may result from fatigue, suffocation, or injury. Prentice and ossiander (1974) described the relationship of velocity and length of time impinged to survival. A $12 \mathrm{~min}$ exposure to $15 \mathrm{~cm} / \mathrm{sec}$ water velocity produced no oxygen stress in salmon fry (Oncorhyncus tshawytscha), but $15 \mathrm{~min}$ at the same velocity produced stress in $25 \%$ of the fry. Juvenile striped bass (Morone saxatilis) survival was slightly less than 908 at $0.15 \mathrm{~m} / \mathrm{sec}$ (Skinner, 1974). Impingement of young-of-year striped bass at 2.2 to $2.8 \mathrm{ft} / \mathrm{sec}$ for $5 \mathrm{~min}$ produced. no mortality, but only $67 \%$ survived $15 \mathrm{~min}$ impingement at the same velocity (Bibko et al., 1974). Mortality caused by fatigue may be due to the accumulation of lactic acid in the blood upsetting the acid-base balance (Beamish, 1966). Screen-induced injury may not cause direct mortality, but probably increases susceptibility to disease and predators. Results obtained in swim speed tests were generally not comparable. Even when the same experimental appartus and procedure was used, Skinner (1974): found performance in identically sized fish differed as much as $40 \%$ from year to year. Bainbridge (1958) found pretest exercise improved swimming performance in some fish species. Swimming ability of young salmon increased $30 \%$ when flowing water rather than static water holding facilities were used (Skinner, 1974). 
Behavioral Responses in Fish

Behavioral barriers (e.g., air bubble screens, illumination, noise, velocity, and turbulence) to aid in excluding fish from water intake structures have been tested. Sonnichsen et al. (1973), $\operatorname{Kerr}$ (1953) and Eicher (1974) found air screens ineffective in restricting fish.passage. Bibko et al. (1974) stated bubble curtains were equally effective in daylight and darkness, but only a $5 \mathrm{~cm}$ gap was needed to permit fish to pass. Air bubble tests conducted by Alevras (1974) on the Judson:River showed apparent success in restricting fish passage, but tests were conducted during a seasonal population low.

Illumination caused both attractive and repulsive responses in fish. Landry and strawn (1974) hypothesized. power plant lights in an estuarine environment attracted fish. Stickney (1971) found juvenile herring were positively phototactic and increased light levels increased activity. Bibko, et al. (1974) observed initial withdrawal from an intensely lighted area, but fish subsequently becalle apathetic to the presence of light. Increased visual cueing. may occur in illuminated intakes.

Sonic harriers using low frequency, high intensity souno frightened fish away at first, but fish shortly became accustomed to sonic barriers (Kerr, 1953). Bell (1973) stated that fish avoid sudden sound or movement, but ignore both if continued for long periods of time. 
Velocity variations have been used successfully in guiding migrating fish species (Schuler, 1974). Unfortunately, variation in fish size, non-uniform flow patterns and other environmental variables make intake velocity gradients impractical. Hazardous, highly turbulent areas were avoided by most fish species (Kerr, 1953). Bell (1973) cited turbulence as a significant cause of injury near intakes.

Schuler (1974) observed dramatic differences in the behavior of large as opposed to small schools with respect to water velocity. Small schools of anchovies fatigued more rapidly. Evidence suggested schooling fishes such as anchovy (Schuler, 1974), golden shiner (Todd et al., 1972) and striped bass and gizzard shad (Bibko et al., 1974) have less complex behavior patterns than non-schooling species. I'he ability of fish to cope with velocity stress may be related to behavioral type or level of social interaction. Eicher (1974) found schooling fish react differently to barriers. In current strong enough to force the school close to a fish guidance device, some species were reluctant to pass through an area too small for a group. As the school swam in front of the diversion, fatigued individuals would finally pass through the opening.

Fish generally exhibit positive rheotaxis, or response to water flow (Fraenkel and Gunn, 1961), by orienting upstream. Kennleyside and Hoar (1954) observed migrating salmon and suggested failure of positive rheotaxis was due 
13

to fatigue. Visual stimuli were also important in rheotaxis. Bibko, et al. (1974) showed striped bass have strong rheotactic response. In still water swimming was random, but all bass oriented upstream when flow resumed. Gray (1937) observed pseudo-rheotaxis, orientation to the rotation of the test tank rather than orientation to water flow, in goldfish tested in various flow patterns. 
THIS PAGE

WAS INTENTIONALLY

LEFT BLANK 


\section{CHAPTER III}

\section{STATEMENT OF THE PROBLEM}

The purpose of this investigation was to study the behavior of juvenile striped bass approximately 8 to $80 \mathrm{~mm}$ in total length swimming at water velocities ranging from 0 to $30 \mathrm{~cm} / \mathrm{sec}$ and at temperatures from 5 to $30 \mathrm{C}$. The research addressed a frustrating problem experienced by many researchers working with the effects of power plant. cooling water intake structures on the aquatic ecosystem. The problem was stated by Bibko, et al. (1974) after extensive research on swim speed and intake related behavior of striped bass and gizzard shad:

"...it would appear that screen intakes should not be as great a problem as it is...intake velocities present at most porver plants 10.5 to $1.0 \mathrm{ft} / \mathrm{sec}$ ) should not impjinge fish such as young striped bass, which may apparently escape water velocities greater than 2.0 to $2.6 \mathrm{ft} / \mathrm{sec}$, if they so chose. Clearly, other parameters such as water temperature and a variety of additional factors ... may modify a fish's normal swimming behavior with respect to water velocity."

Tests of stamina and swim speed (e.g., Bainbridge, 1958 and Brett, 1967) provide quantitative tolerance limits, but fail to consider qualitative behavioral effects of velocity on activity or the effect of such variations in activity on susceptibility to impingement. This study sought to go beyond stamina and swim speed tests to consider questions related to activity patterns. Also, few 
observational data on young striped bass are available. Juvenile fish are an important life stage in assuring continued population success and at the same time they are highly susceptibile to entrainment and impingement.

Striped bass ("stripers" or "rockfish") are valuable sport fish which occur naturally along the east coast of the United States from the St. Lawrence River in Canada to the Tchefuncta River in Louisiana. In 1879 striped bass were introduced into the Sacramento - San Joaquin river system in California and are now found along much of the west coast. (Goodson, 1966). In the early 1950's landlocked populations were found following the impoundment of Santee-Cooper Reservoir (Stevens, 1958). Since the discovery of freshwater resident populations of this normally anadromous species, large reservoirs have been stocked by many states.

Striped bass were chosen as the experimental species not only because they are a widely distributed, valuable sport fish which state conservation agencies have expended large amounts of money and energy establishing, but $\underline{\text { M. }}$ saxatilis is also a top carnivore in the aquatic food web and large losses of carnivores due to entrainment/impingement have unknown environmental consequences. Striped bass feed on crustaceans and fish such as clupeids and an occasional game species. As a predator, striped bass have often been stocked for threadfin shad control (Goodson, 1966). 


\section{Assumptions}

Five experimental assumptions were made.

1) Hatchery spawned, laboratory reared striped bass were assumed to display typical behavioral response patterns found in "wild" fish.

2) The test channel design was assumed to simulate a fixed screen intake structure.

3) The non-laminar flow caused by the circular nature of the test channel was held to closely duplicate the turbulent flow conditions typical of the nearscreen area of intakes.

4) Levels of illumination necessary for observation and filming were assumed to have little effect on fish behavior.

5) The presence of a partially hidden observer was assumed to have little effect on the behavioral response of striped bass. 
THIS PAGE

WAS INTENTIONALLY

LEFT BLANK 
CHAPTER IV

METHODS AND MATERIALS

\section{Larval Striped Bass Observations}

Eight to fourteen-day old striped bass spawned from Cherokee Reservoir adults were obtained from the Tennessee Game and Fish Commission at Morristown, Tennessee. Bass, were held and tested in a $120 \mathrm{~cm}$ diameter circular fiberglass tank when they were $8 \mathrm{~mm}( \pm 2 \mathrm{~mm}$ standard deviation) total length. The larval fish were acclimated and tested at $20( \pm 2) \mathrm{C}$, a water temperature similar to that found in the larval environment. Activity was observed at water velocities of 0 and $3 \mathrm{~cm} / \mathrm{sec}$ with and without food present. Food organisms were obtained by plankton tows in fish culture ponds near the laboratory. Composition of the tows varied, but rotifers and Daphnia occurred in great abundance. Swimming activity was recorded as young striped bass moved over a numbered grid during l-min observation periods: The activity grid was drawn on a rigid white plastic sheet that was suspended 5 -centimeters below the water surface of the holding tank (Figure 1). The $30 \times 30$ $\mathrm{cm}$ grid had a total area of $900 \mathrm{~cm}^{2}$ marked as 100 numbered $3 \mathrm{~cm}$ squares.

Observations consisted of voice recordings of the 1-min activity of individual fish. The recording was then transferred to paper from which the total area covered 
ORNL-DWG $76-7370$

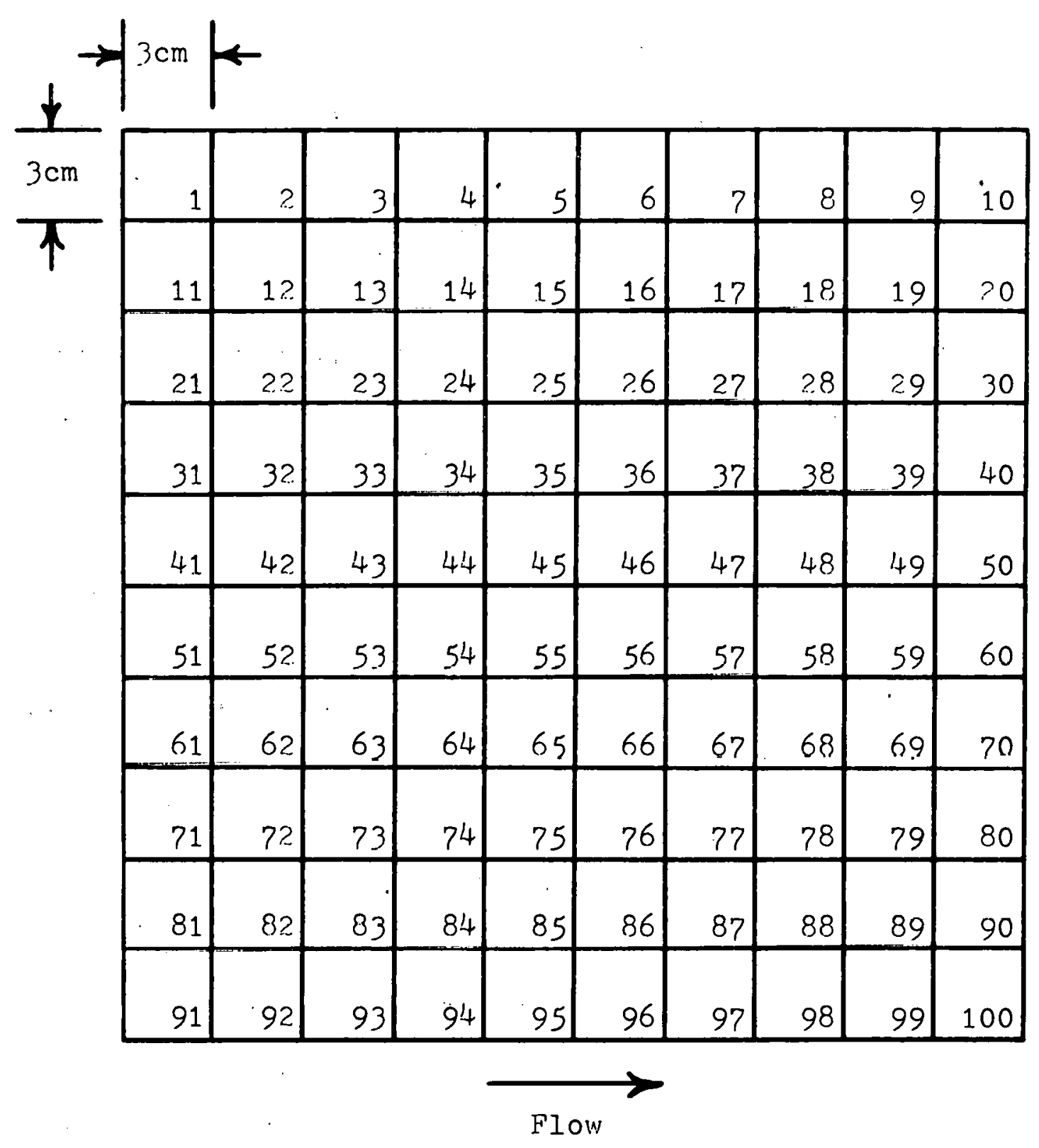

Figure 1. A numbered background grid was used to monitor the activity of larval striped bass. 
during each activity period and the total distance traveled were computed. Twelve 1-min observations were made five minutes apart at two water velocities with and without food: $0 \mathrm{~cm} / \mathrm{sec}$ with food, $0 \mathrm{~cm} / \mathrm{sec}$ without food, $3 \mathrm{~cm} / \mathrm{sec}$ with food, $3 \mathrm{~cm} / \mathrm{sec}$ without food.

The following techniques were employed during recording and analysis of observational data. As the premaxillary of an observed individual crossed the border of a square the number of that square was recorded. When measurements for data analysis were made, each distance was measured from the center of one square to the center of the next square occupied. Area occupied during each movement was considered to be the total area of the square, and any square not actually occupied, but entirely enclosed by a circular swimming,path was included in the area ranged by an individual.

Data were analyzed by three methods. A two-way anlaysis of variance was performed for both area and distance at the two test velocities. A plot of area vs distance was made. The mean value and standard deviation for each set of experimental conditions were determined.

\section{Juvenile I Striped Bass Observations}

Striped bass retained at the completion of larval bass observations were held at $20( \pm 2)$. C until the desired body length had been attained. A larger, $180 \mathrm{~cm}$-diameter circular fiberglass tank was used as an observation chamber (Figure 2). 


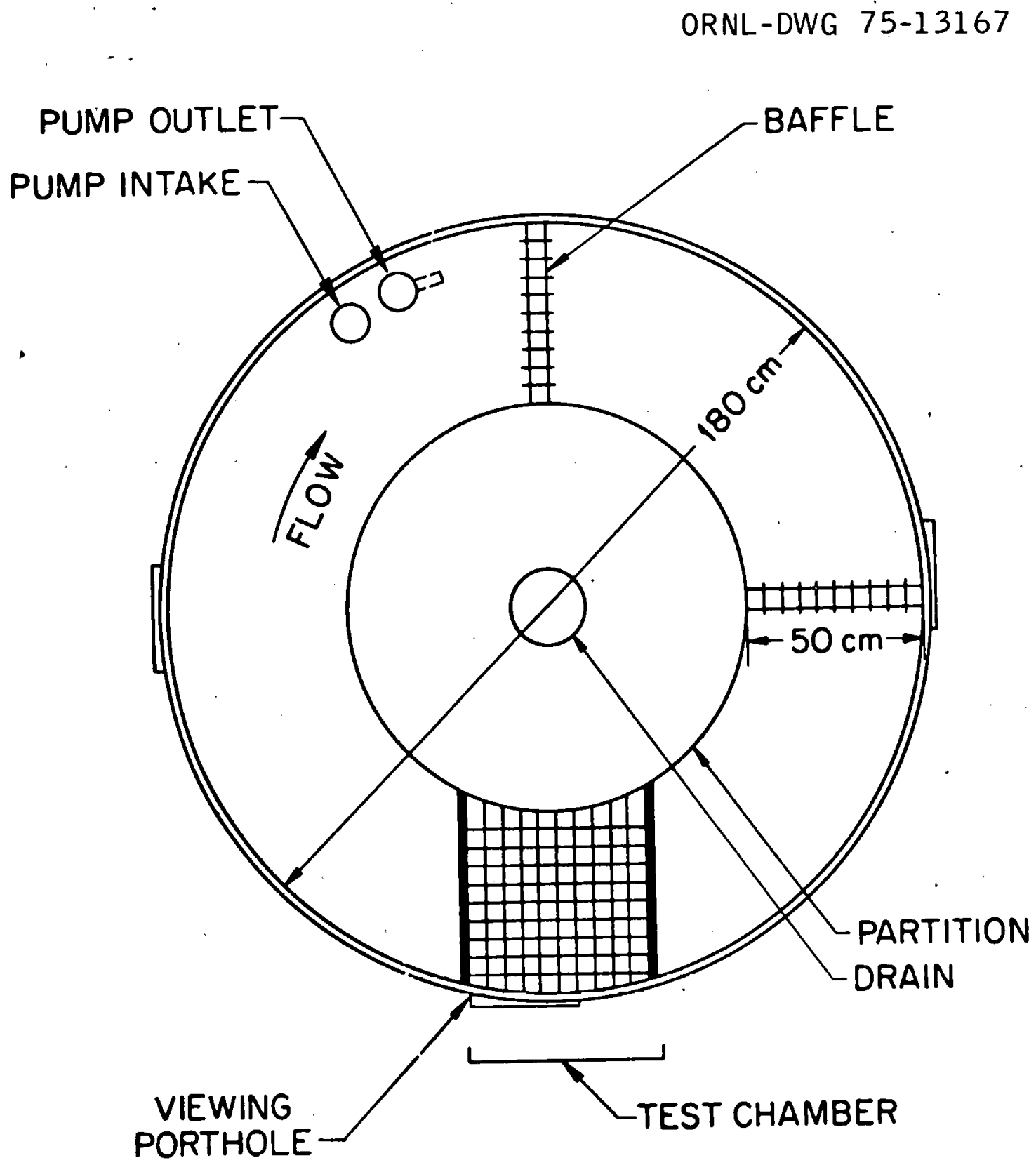

Figure 2. Tank modifications included portholes, a circular partition, baffles, and a test chamber with a numbered grid on the bottom for monitoring fish activity. 
Modifications included side-view portholes, a circular partition to create a $50-\mathrm{cm}$ wide by $30-\mathrm{cm}$ deep channel, a series of baffles to reduce turbulence, and an application of white paint to inside surfaces to provide greater visibility. Two $2 \mathrm{~mm}$ mesh screens blocked the upstream and downstream ends of the $2025 \mathrm{~cm}^{2}$ test area. A numbered grid drawn on the bottom of the test area was used to locate fish. Curtains isolated the tank from external disturbance. In addition to flourescent room light, a 150-watt flood light illuminated the test area to allow motion picture filming of fish activity. Water velocities were generated by a $1200 \mathrm{l} / \mathrm{min}$ pump and test velocities were determined by timing the travel of a float over a known distance. Differences in water velocity between the inner and outer channel walls at $15 \mathrm{~cm} / \mathrm{sec}$ was negligible $(<0.1 \mathrm{~cm} / \mathrm{sec}$ at the surface) when tested with a float. Velocity measurements made at various depths with an electromagnetic current meter equiped with a microprobe indicated an increase in velocity variations as the probe was moved downstream within the test chamber.

$$
\text { Fish of } 10( \pm 3), 25( \pm 5) \text {, and } 50( \pm 3) \mathrm{mm} \text { total }
$$

length were tested at velocities of $0,3,15$, and $27 \mathrm{~cm} / \mathrm{sec}$ with and without food present. Artemia nauplii were homogeneously distributed in the test chamber when experimental groups were tested for ability to forage at the various water velocities. 
Groups of 20 juvenile striped bass were placed in the test chamber at $20( \pm 1) \mathrm{C}$ and allowed to acclimate for 30min at $0 \mathrm{~cm} / \mathrm{sec}$. Any fish showing symptoms of stress or shock due to handling were replaced. In all cases shock and mortality due to handling were observed in less than $10 \%$ of the test group. The decision to use 20 individuals per test was based on preliminary observations. One 25-mm juvenile bass was placed in the test chamber and the activity recorded. Other striped bass were added one at a time and the activity of the first fish recorded after each addition. Visual contact is important in schooling fish and optimal density without crowding was determined.

Following acclimation, a series of several threeminute observations of the movements of individual fish were recorded and the entire test group was filmed for several minutes. The water velocity was increased, a 30-min acclimation period allowed, and observations again recorded. Voice recordings of numbers were taken from the background grid pattern as the observed fish moved within the test area. Activity was transposed to a paper replica of the grid pattern and the area covered during an activity period was calculated. For example, a $25-\mathrm{mm}$ fish ranged $425 \mathrm{~cm}^{2}$ per minute in a circular swimming pattern (Figure 3 ).

Individual frames from movies taken during observation periods for various combinations of fish size, velocity, and feeding were projected onto a piece of paper to determine 
ORNL-DWG 75-13641

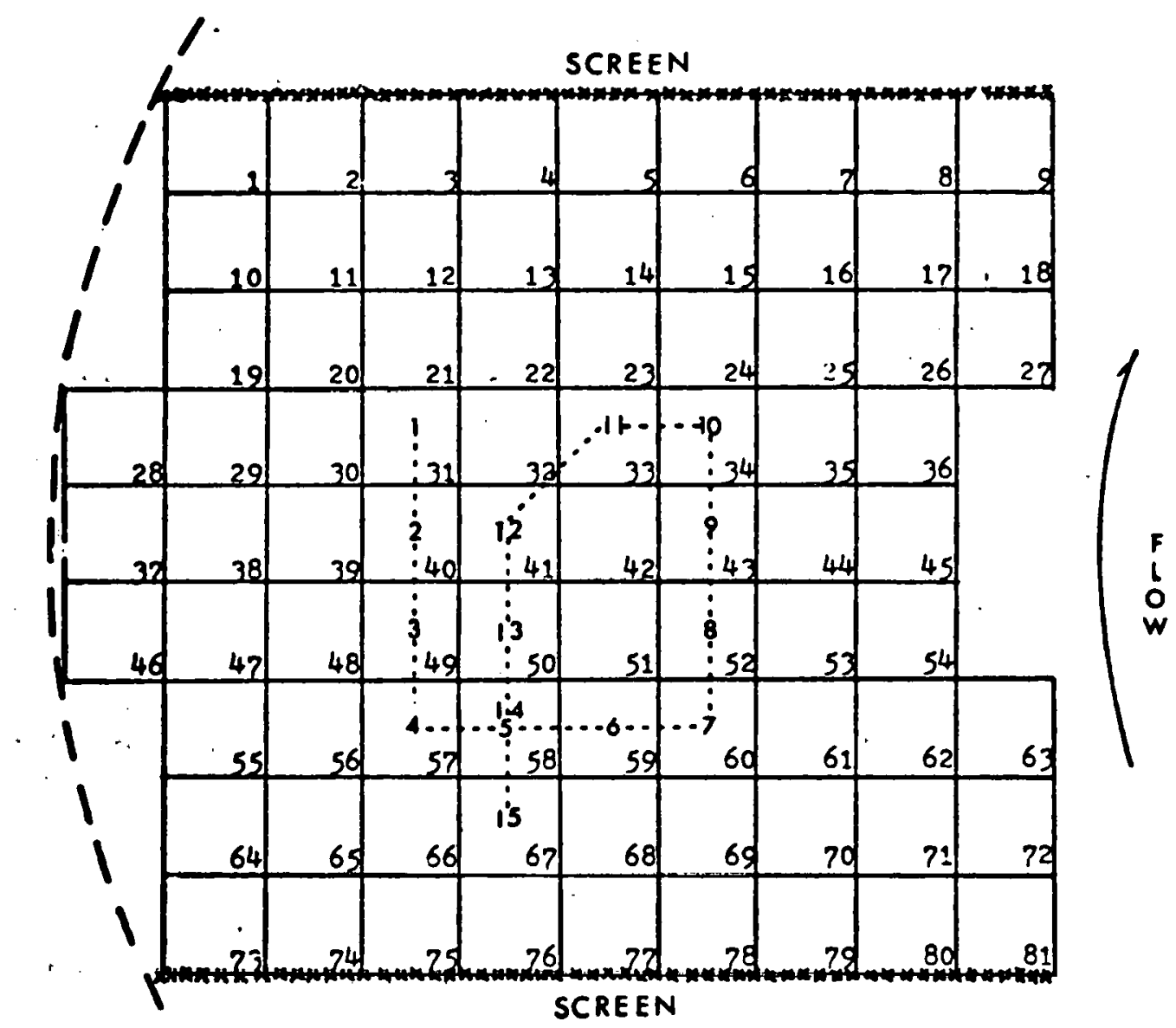

Figure 3. The 1-min activity pattern of a $25 \mathrm{~mm}$ juvenile striped bass at a water velocity of $15 \mathrm{~cm} / \mathrm{sec}$ is superimposed on a replicate of the grid pattern used to monitor activity of juvenile bass 10 to 50 mm long. 
distance between fish. A transect was drawn at a random distance from the profected image of the outer wall of the test chamber. At random points along the transect the distance between the premaxillaries of two fish on opposite sides of the line was measured. Three measurements were made for each of five frames taken from movies of the three sizes of fish under the four water velocities in the presence and absence of food, a total of 360 data points. Distance in centimeters was convereted to body lengths and regressed on velocity.

Movies were also used to analyze the orientation of the fish with respect to water current. Positive rheotaxis (P) described a fish actively swimming against the current, while negative rheotaxis (N) described downstream orientation. Lateral orientation (L) occurred when a fish positioned the long axis of its body perpendicular to stream flow. The orientation of 72 fish during three minute activity periods tested at combinations of velocity, fish size and the presence or absence of food was converted to percentage and the means calculated.

Data obtained from the test groups were subjected to three treatments. Analysis of variance was used to assess the signifance of fish size, water velocity, and presence/ absence of food on the total area occupied by individual fish. The effect of water velocity and feeding activity on the distance between fish was analyzed. The mean percentage of time spent in positive, lateral, and negative 
rheotaxis describing the relationship of a swimming fish orienting with respect to three water velocities was compared.

\section{Juvenile II Striped Bass Observations}

The experimental procedure for this set of experiments was similar to that used in observations of entrainable juvenile I striped bass. The modified $180 \mathrm{~cm}$-diameter tank, $1200 \mathrm{l} / \mathrm{min}$ pump, fluorescent lighting and curtain isolating the test tank all remained the same. Twelve millimeter heavy-duty mesh screens similar to those currently used in intake structure were placed at the upstream and downstream ends of the test chamber. Background grid pattern changes were also necessary to accomodate impingeable striped bass of $80( \pm 7) \mathrm{mm}$ total length. Individual squares were enlarged to $10 \times 10 \mathrm{~cm}$ and the test area now measured $5,300 \mathrm{~cm}^{2}$ (Figure 4).

Effects of interactions between velocities of $0,5,15$, and $30 \mathrm{~cm} / \mathrm{sec}$ and temperatures of $5,10,15,20,25$ and 30 $C$ on the area ranged and distance traveled by juvenile striped bass were investigated. Fish were acclimated from holding temperatures at the rate of $1 \mathrm{C}$ per day until final test temperature was obtained. All juveniles were acclimated at test temperatures for at least seven days prior to velocity testing.

Groups of 10 striped bass were placed in the test chamber. In each case experiments were conducted at the 
ORNL-DWG 76-7.369

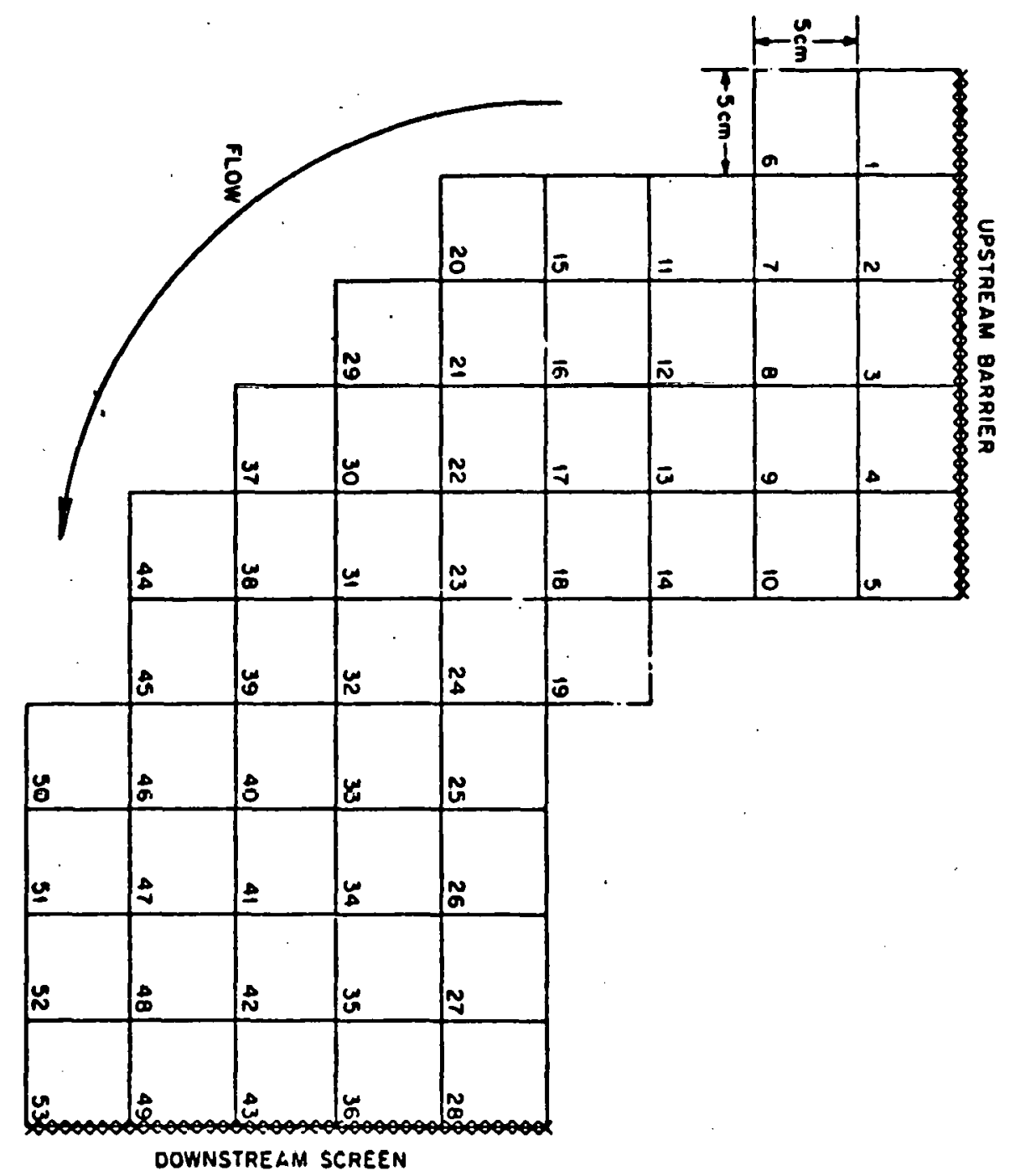

Figure 4. The background grid pattern for monitoring activity of $80 \mathrm{~mm}$ juvenile striped bass. 
acclimation temperature \pm 1 C. A 30-min waiting period at $0 \mathrm{~cm} / \mathrm{sec}$ allowed the juveniles to recover from handling stress induced by netting and transfering from holding tanks to the test chamber. The pump was started, the desired velocity obtained, and observations begun. Observation periods lasted five hours for each temperature and velocity combination. Observations again consisted of voice recordings of grid numbers for fish which moved across a background grid pattern drawn on the floor of the tank. Three recordings of individual fish were made at each time interval: $15,30,45,60,90,120,150,180,210,240$, 270 , and $300 \mathrm{~min}$. As before, numbers were transferred to a paper replica of the background grid.

Data were analyzed using three-way analysis of variance to test the significance of temperature, velocity, and length of time swimming on the area covered and distance traveled by impingeable-size striped bass. Mean percentage of movements which were oriented positively, negatively, and laterally to flow were analyzed.

Some additional investigations were conducted. At $20 \mathrm{C}$ and velocities of 15 and $30 \mathrm{~cm} / \mathrm{sec}$ a large eddy current was generated in the test chamber to observe effects of turbulence on the swimming performance of fish. In another series of experiments at $15 \mathrm{C}$ and flows of 15 and $30 \mathrm{~cm} / \mathrm{sec}$, a fish blinded by ocular puncture in both eyes was introduced with 9 normal conspecifics and behavioral observations made. 
Data obtained from turbulence and blind fish experiments were compared to temperature/velocity data obtained from other juvenile striped bass. 


\section{CHAPTER V}

\section{RESULTS}

Results of Larval Striped Bass Observations

Activity of striped bass less than $10 \mathrm{~mm}$ long was greatly influenced by a small change in velocity. Analysis of variance indicated an increase in velocity from 0 to 3 $\mathrm{cm} / \mathrm{sec}$ caused a highly significant $(P<0.001)$ decrease in. both the area (Table 1) and distance (Table 2) traveled by larval fish. Great similarity in the magnitude of the Fvalues for the effects of water velocity on area and distance traveled were observed when the two tables were compared. The effect of presence or absence of natural food on the area and distance traveled by larval striped bass was less than the effect of velocity, but still highly significant $(P<0.001)$. Again, a comparison of the $F$-values revealed the two values, distance and area, had similar magnitude. Interactions between water velocity and presence/absence food were not significant $(P>0.05)$.

At both 0 and $3 \mathrm{~cm} / \mathrm{sec}$ striped bass traveled greater distances with food available than without food (Figure 5A). Area ranged by 12 individuals during 1-min observations also increased when food was oresent (Figure 5B). Visual observations indicated larval striped bass fed continuously. Feeding activity accounted for most locomotion at $0 \mathrm{~cm} / \mathrm{sec}$. 
Table 1. Analysis of variance showing the effect of water velocity and the presence of food on area traveled by larval striped bass during 1-min observation periods.

\begin{tabular}{lrrr}
\hline \hline Source of Variation & df & \multicolumn{1}{c}{ MS } & \multicolumn{1}{c}{ F } \\
\hline Water velocity & 1 & $47,062.7$ & $146.2^{\mathrm{a}}$ \\
Food present/absent & 1 & $8,034.2$ & $24.9^{\mathrm{a}}$ \\
Water velocity x food & 1 & 15.2 & $0.1^{\mathrm{b}}$ \\
Error & 44 & 322.0 & -- \\
Total & 47 & $1,474.0$ & -- \\
\hline
\end{tabular}

${ }^{a}$ Significant at $\mathrm{P} 0.001$.

$b_{\text {Not Significant at } P} 0.05$.

Table 2. Analysis of variance showing the effect of water velocity and the presence/absence of food on distance traveled by larval striped bass during 1-min observation periods.

\begin{tabular}{lrrr}
\hline Source of Variation & df & MS & \multicolumn{1}{c}{ F } \\
\hline Water velocity & 1 & $5,874.2$ & $135.7^{\mathrm{a}}$ \\
Food present/absent & 1 & $1,912.7$ & $44.2^{\mathrm{a}}$ \\
Water velocity x food & 1 & 1.7 & $0.1^{\mathrm{b}}$ \\
Error & 44 & 43.3 &.- \\
Total & 47 & 206.2 & -- \\
\hline
\end{tabular}

$a_{\text {Significant at } P} 0.001$.

$\mathrm{b}_{\text {Not Significant at } \mathrm{P}} 0.05$. 
ORNL-DWG - 76-7368
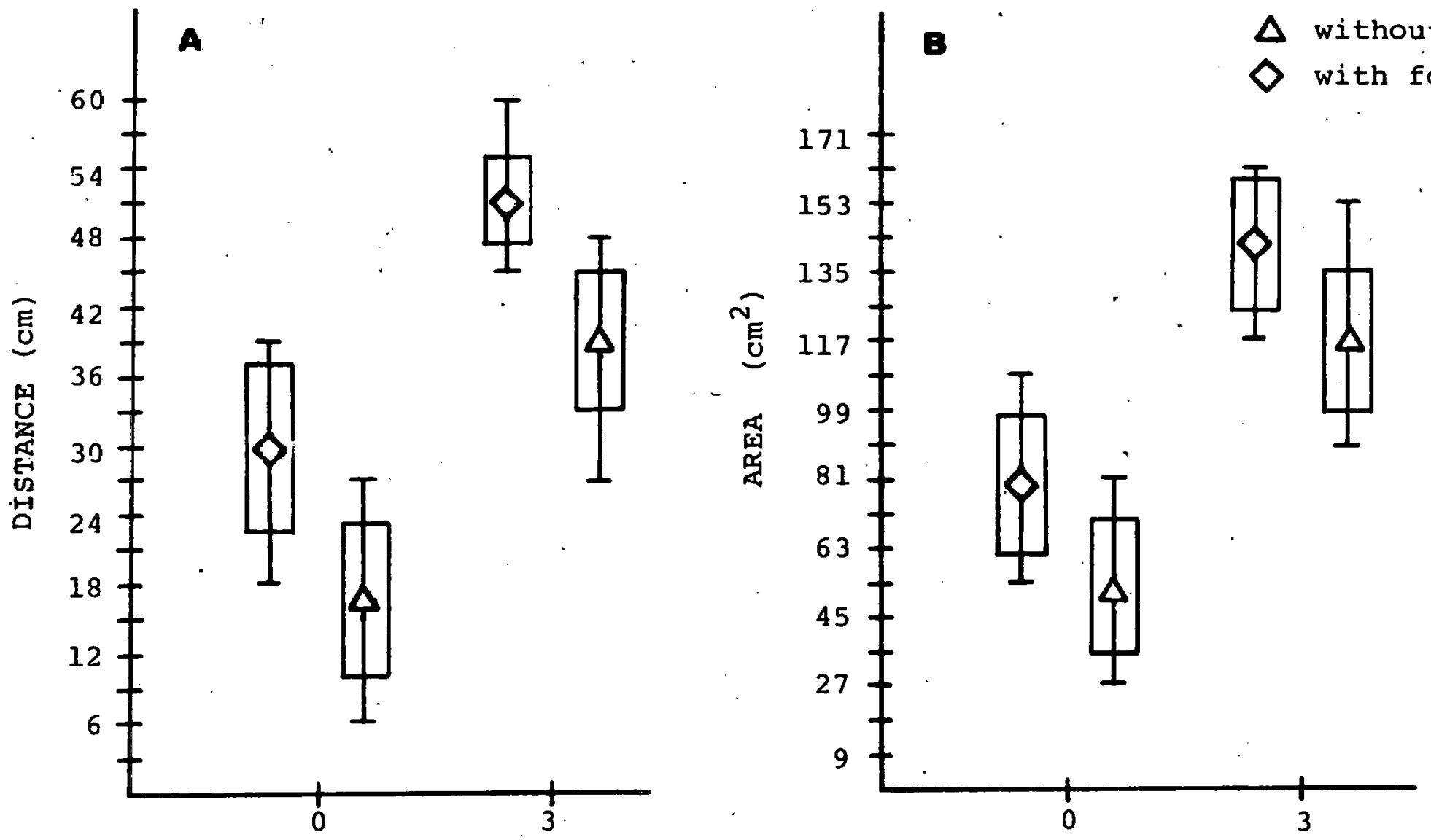

Water Velocity $(\mathrm{cm} / \mathrm{sec})$

Figure 5. Distance traveled (A) and area ranged (B) by larval striped bass at two velocities during $1-m i n$ activity periods. Bars indicate one standard deviation and symbols show the mean. Brackets represent the range of twelve samples. 
Larval fish tested at $0 \mathrm{~cm} / \mathrm{sec}$ without food present generally sank slowly. One individual came to rest on the plastic observation grid and remained in stationary contact for several minutes. Food organisms were generally positively phototactic and remained near the surface of the tank. Large numbers of young striped bass cluster at the water surface near aggregations of Daphnia.

Larval bass covered more distance and area in the higher velocity flow. When the water velocity increased to $3 \mathrm{~cm} / \mathrm{sec}$ most food organisms drifted with the water flow. Striped bass fry repeatedly oriented upstream, swam a short distance while feeding, and then drifted downstream. When no food was present at $3 \mathrm{~cm} / \mathrm{sec}$, larval bass alternately swam and drifted for short distances.

Area and distance covered increased proportionately (Figure 6). Area and distance were plotted simultaneously and a line indicating those points where distance and area had a one to one relationship was drawn. Points above the line indicated a circular swimming pattern. Points falling on the line indicated unidirectional movement. Points below the line represented individuals displaying the swim/ drift activity pattern. Few circular swimming patterns were exhibited by larval bass. The swim drift activity pattern occurred most frequently.

No fright response was observed in larval striped bass less than $10 \mathrm{~mm}$ long. There was no indication the young bass were aware of motion or presence of the investigator. A hand 
ORNL-DWG 76-7367

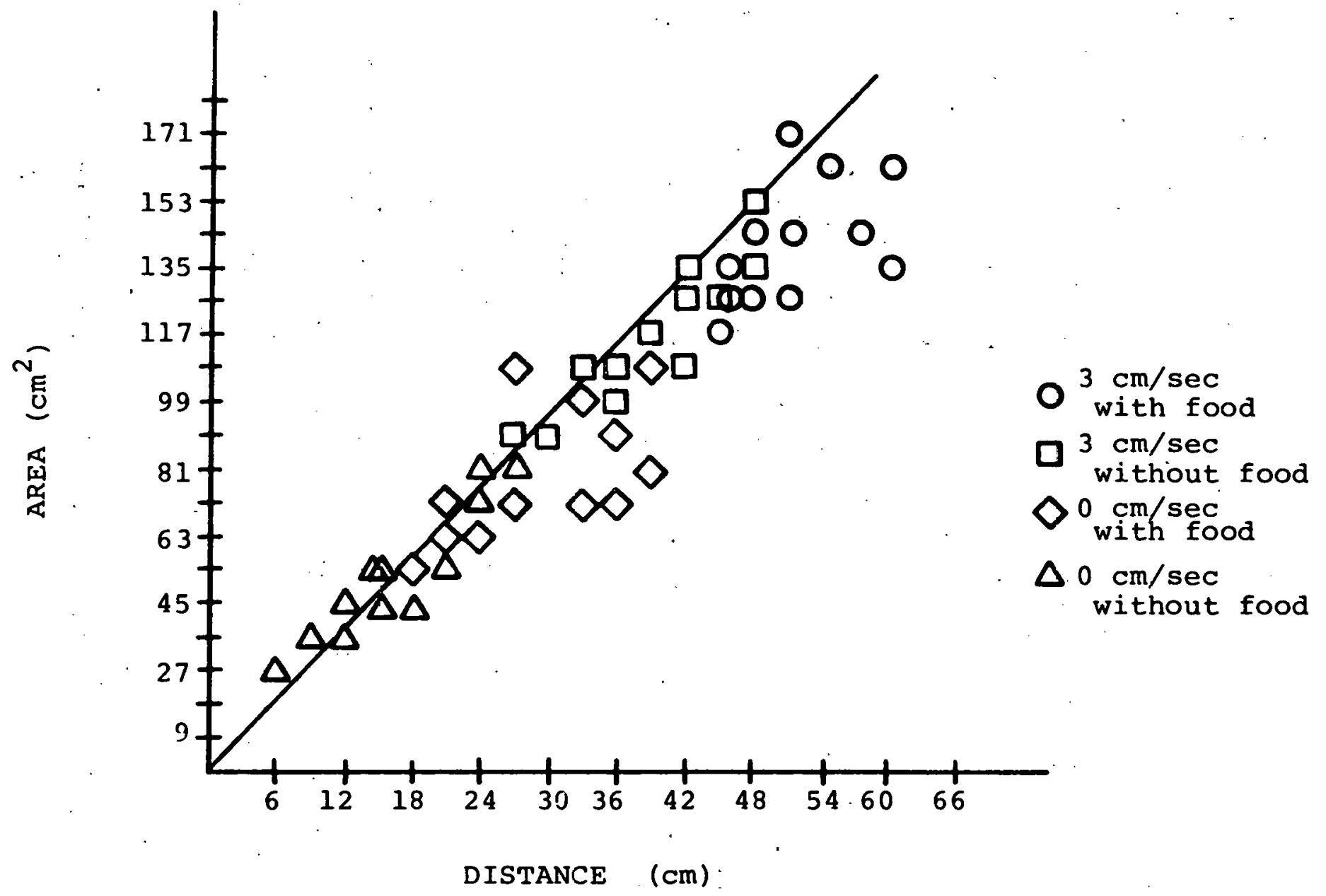

Figure 6. Area and distance traveled by larval striped bass at $0 \mathrm{~cm} / \mathrm{sec}$ and $3 \mathrm{~cm} / \mathrm{sec}$ with and without food present. The line indicates a $1: 1$ relationship of distance: area traveled. 
passed quickly a few centimeters above the water surface caused no response; yet even the gentlest handling caused high mortality.

No schooling activity was observed; each individual moved independently of other bass. Some visual cueing was observed in the feeding response. Although larval fish occupied the entire $90 \mathrm{~cm}$ vertical water column, the greatest number were within $30 \mathrm{~cm}$ of the surface whether food was present or not.

Results of Juvenile I striped Bass Observations.

Area occupied by a single $25-\mathrm{mm}$ striped bass was monitored as 19 additional bass were placed in the test chamber one at a time (Figure 7). The original striped bass occupied less and less area until a total of 12 juveniles were present. A total of $20 \mathrm{fish}$ were placed in the tank, but after the first 12 individuals were added little change in area occupied was observed. No apparent crowding stress was observed when experimental groups of 20 were used. - of the variables tested, water velocity had greatest significnat impact on area traveled during 3-min activity observations (Table 3). Area decreased as velocity increased. Fish size and presence or absence of food had lesser, yet highly significant effects on range. Interaction between water velocity and fish size was more significant than other interactions affecting area juvenile striped bass were able to cover. 
ORNL-DWG 76-7366



Figure 7. Area traveled during a 3-min observation period as a function of the number of $25 \mathrm{~mm}$ juvenile striped bass present in the test chamber. The curve was fitted by eye. 
Table 3. Analysis of variance showing the effect of fish size, water velocity, and presence/absence of food on the area traveled by juvenile striped bass 10 to $50 \mathrm{~mm}$ long during 3-min observation periods

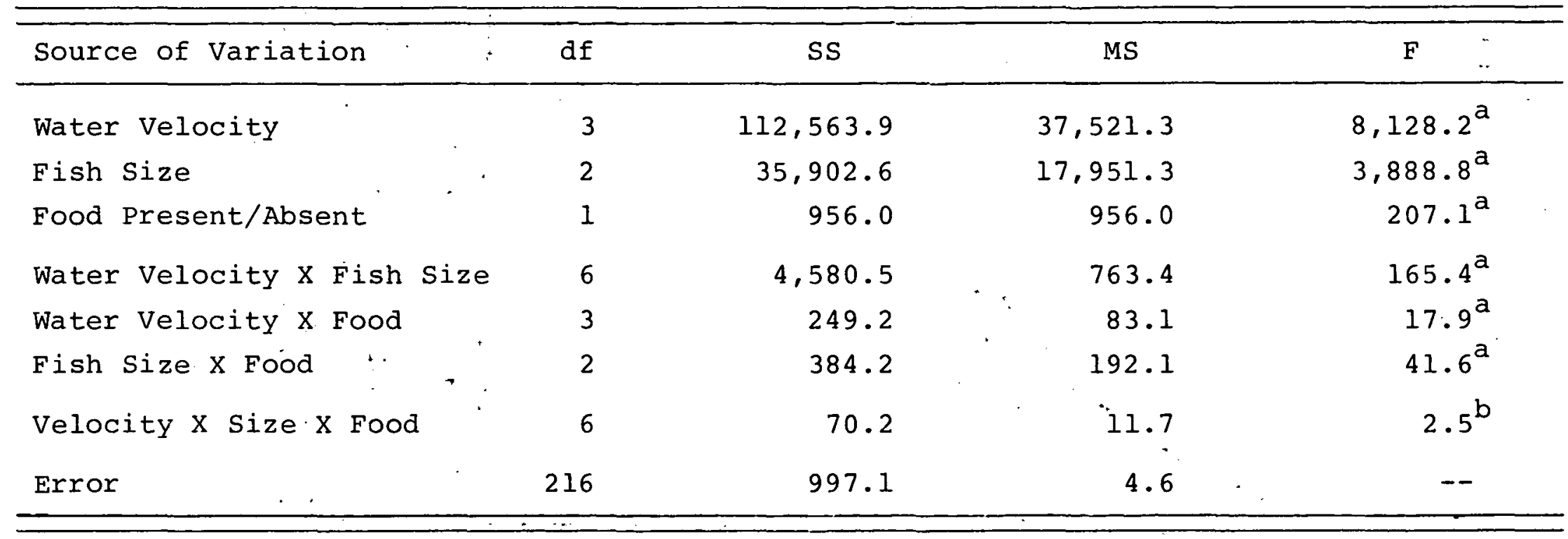

${ }^{a}$ Significant at $\mathrm{P}<0.001$.

${ }^{b}$ Not Significant at $P<0.05$. 
Increased water velocity significantly decreased the area ranged by 10,25 , and 50-mm juvenile striped bass in the absence of food $(P<0.05)$ (Figure $8 A)$. No significant difference was found among the slopes of the regression lines for the three fish sizes, indicating that the magnitude of the area covered was proportional to the size of the fish. Area covered by 10-mm juveniles during 3-min activity periods at $27 \mathrm{~cm} / \mathrm{sec}$ was nearly an order of magnitude less than area covered under static conditions.

Presence of brine shrimp (Figure 8B) significantly reduced the area ranged by all juvenile fish tested $(P<0.01)$. The small size of the food organisms may have biased the data. Fish 10 and $25-\mathrm{mm}$ in length reacted quickly and visibly to the presence of food while the reaction of $50-\mathrm{mm}$ fish was subdued and nearly imperceptible. Area foraged by juvenile fish was porportional to fish size. For all juveniles tested the effects of increased water velocity were more marked in the absence of food.

Distance between fish decreased as water velocity increased (Figure 9). The presence of food significantly $(P<0.05)$ reduced distance between 10 and $25-\mathrm{mm}$ striped bass. Spacing between $50-\mathrm{mm}$ juveniles was not significantly reduced by the presence of food. The 10-mm fish under static conditions maintained the greatest inter-fish distance in body lengths between fish. Actual body contact was observed infrequently among $10-\mathrm{mm}$ bass at $27-\mathrm{cm} / \mathrm{sec}$ and no contact 
ORNL-DWG 75-13639

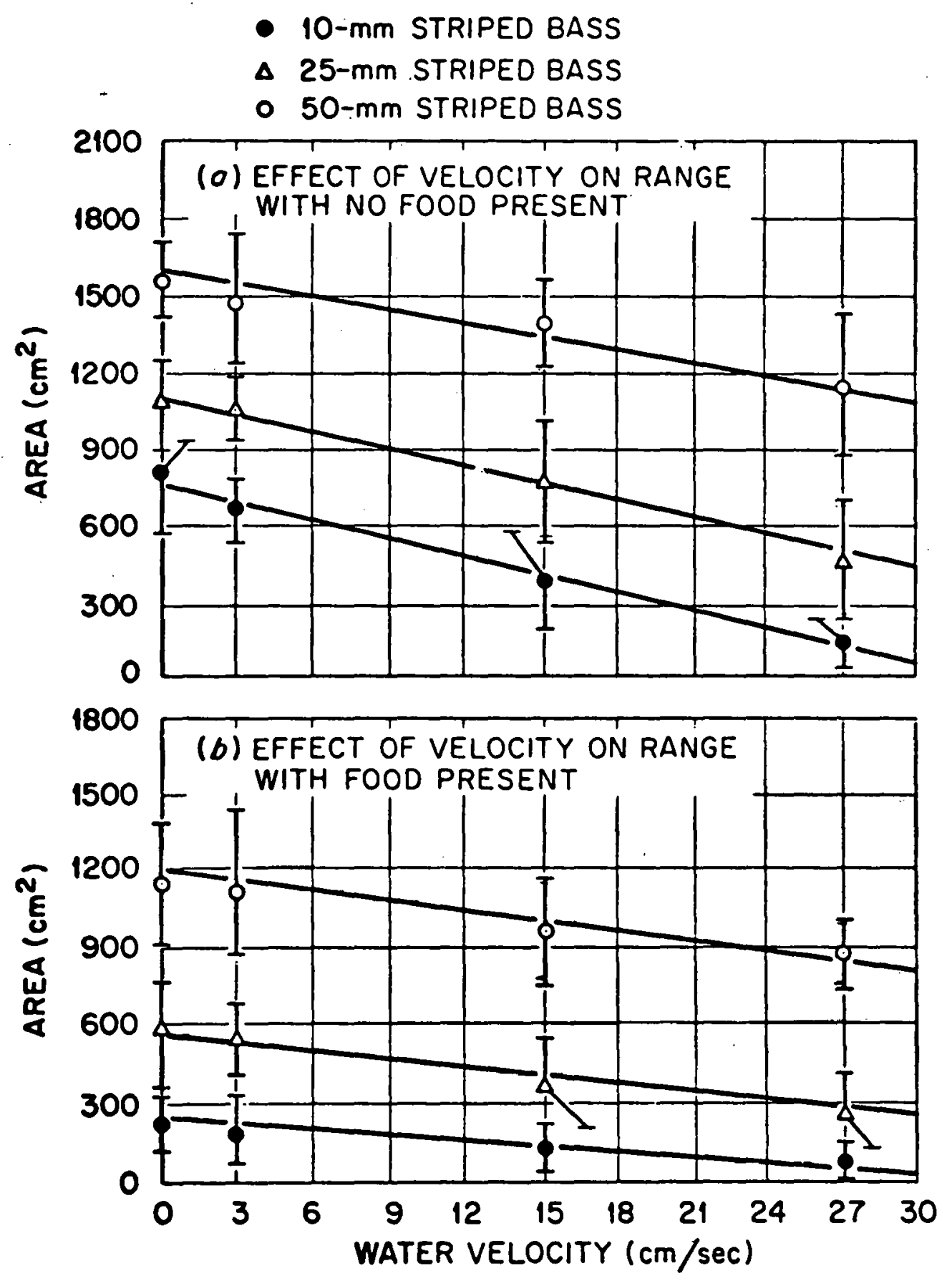

Figure 8. The effect of increasing velocity on juvenile striped bass mobility in the presence and absence of food. Each data point represents mean area occupied by 20 each of fish during a 3 -min observation period. Brackets show one standard deviation. 
ORNL-DWG 75-13640

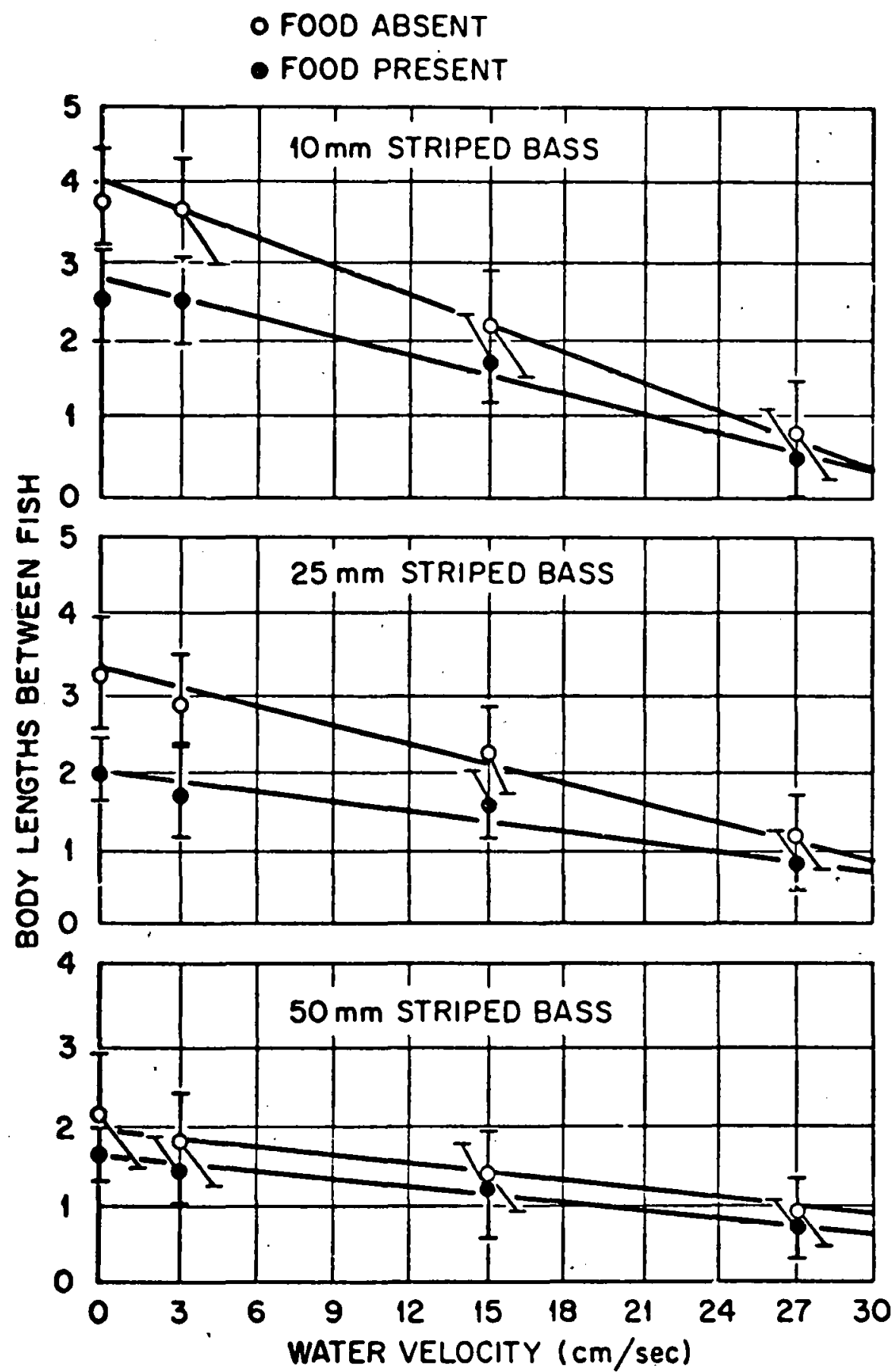

Figure 9. The relationship of water velocity and distance between fish for 3 sizes of juvenile striped bass. Each point represents the mean from 15 samples. Brackets show one standard deviation. 
was observed for larger fish. A minimum spacing equal to at least 0.5 body length was maintained by the majority of test fish.

Positive rheotaxis was generally the dominant orientation and was exhibited 25 to $81 \%$ of the duration of each observation (Figure 10). At a water velocity of $3 \mathrm{~cm} / \mathrm{sec}$ young striped bass spent nearly equal amounts of time in positive, lateral and negative rheotaxis. Lateral rheotaxis decreased as velocity. increased ranging from $40 \%$ at $3 \mathrm{~cm} / \mathrm{sec}$ to 38 at $27 \mathrm{~cm} / \mathrm{sec}$. Negative rheotaxis was variable, but generally decreased as velocity increased ranging from $39 \%$ to 88 of a 3-min activity period. Presence of food had little impact on rheotactic response.

When no food was present young striped bass often remained in the lower third of the $30-\mathrm{cm}$ deep water column. Occasionaily 25 and $50-\mathrm{mm}$ tish rōse to the upper thilrd uf the water column under low flow conditions. At $27 \mathrm{~cm} / \mathrm{sec}$ all fish observed remained very close to the bottom of the test chamber. Little attraction to the sides of the test chamber was observed.

When food was present vertical movement occurred throughout the water column at all water, velocities tested except $27 \mathrm{~cm} / \mathrm{sec}$. A weakly sterotyped feeding sequence was observed. Once visual contact with prey was made, young bass darted upstream quickly, engulfed the organism, and sank down within the water column about two body depths. 

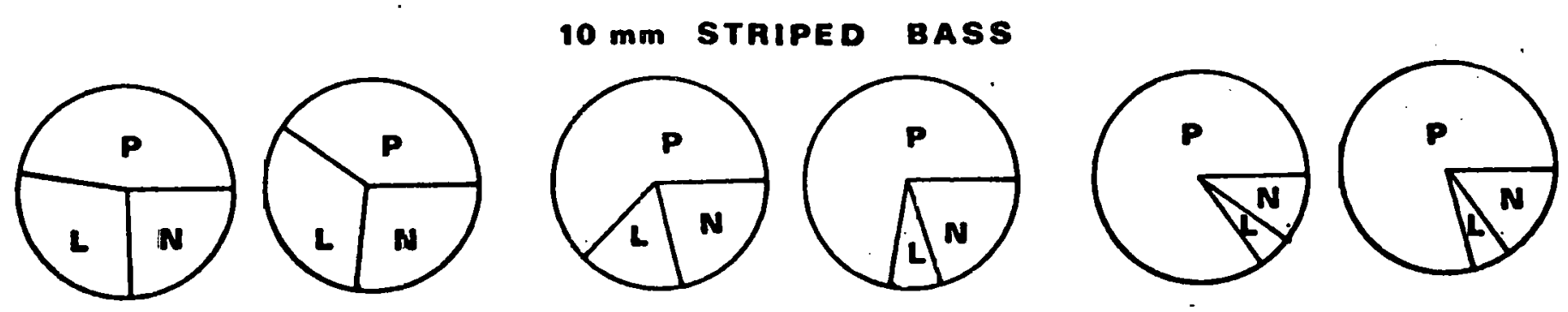

\section{$25 \mathrm{~mm}$ STRIPED BASS}
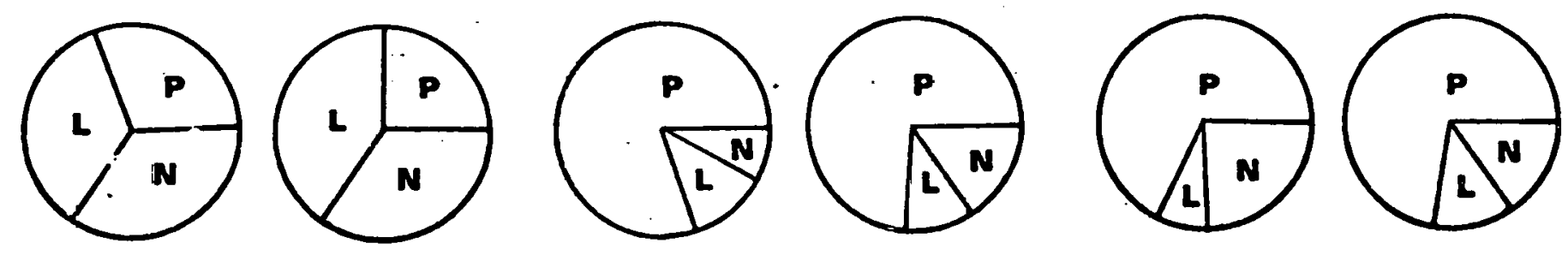

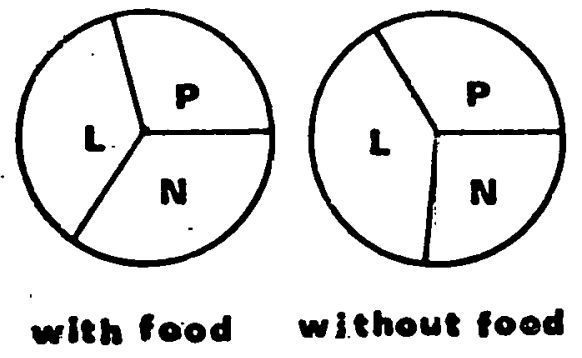

$-3 \cos / 800$

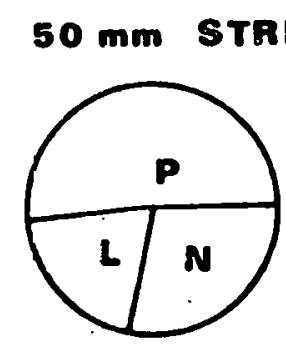

with food without food

15. $\mathrm{em} / \mathrm{eec}$
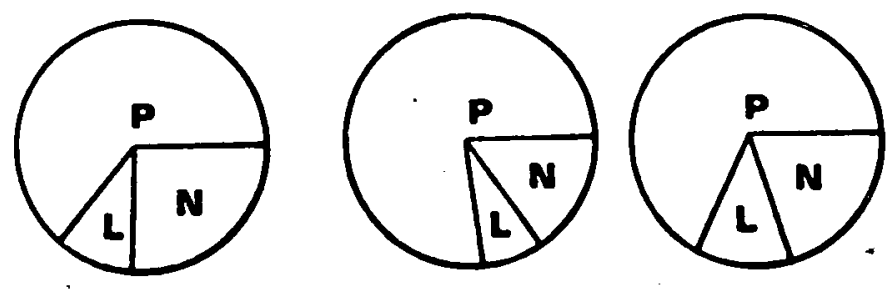

with food without food

$27 \mathrm{em} / 000$

Figure 10. Mean percentage of the 3-min observation spent in positive (P), negative (N), or lateral (L) rheotaxis at the various test velocities. Each section represents the mean of 3 observation periods. 
Fish then returned to approximately the area where prey had first been sighted. Several feeding sequences were rapidly repeated in the same location. Awareness of the downstream screen apparently decreased during feeding; several apparently unstressed fish made caudal fin contact with the screen at velocities of 15 and $27 \mathrm{~cm} / \mathrm{sec}$.

All 25-mm juvenile striped bass displayed a swimming posture different from other size fish. While 10 and $50-\mathrm{mm}$ bass swam with the long axis of the body parrallel to the bottom of the tank during all activity except vertical movement, over 100 measurements made on isolated frames of movie film showed 25-mm fish swam constantly at a heads-up angle of $20^{\circ}\left( \pm 3^{\circ} \mathrm{s.d.}\right)$ with respect to the bottom of the tank. Results of Juvenile II Striped Bass Observations

Analysis of variance demonstrated water temperature had the most significant $(P<0.001)$ effect on area ranged (Table 4 ) and distance traveled (Table 5). Water velocity and length of time swimming had a lesser, yet still significant $(P<0.001)$ influence on the area and distance covered by 80 $\mathrm{mm}$ juvenile striped bass during one minute observations. When the two F-values were compared area values were consistently greater than distance values in all highly significant interactions.

Area and distance traveled decreased as water velocity increased (Figure 11). Mean values of 72 samples tested at each speed went from $187 \mathrm{~cm}$ traveled while ranging a mean area 
Table 4. Analysis of variance showing the effect of temperature, water velocity, and duration of the experiment on area ranged by juvenile striped bass $80^{\circ} \mathrm{mm}$ long.

\begin{tabular}{lrrr}
\hline Source of Variation & df & MS & \multicolumn{1}{c}{ F } \\
\hline Water Temperature & 5 & $163,000.5$ & $1303.8^{\mathrm{a}}$ \\
Water Velocity & 3 & $82,274.5$ & $658.1^{\mathrm{a}}$ \\
Time Swimming & 11 & $11,561.9$ & $92.5^{\mathrm{a}}$ \\
Velocity X Temperature & 15 & $2,544.8$ & $20.4^{\mathrm{a}}$ \\
Velocity X Time & 33 & 179.5 & $1.4^{\mathrm{b}}$ \\
Time X Temperature & 55 & 115.7 & $0.9^{\mathrm{C}}$ \\
Error & 165 & 125.0 & -- \\
\hline
\end{tabular}

a Significant at $\mathrm{p}<0.001 . \quad \mathrm{C}_{\text {Not }}$ Significant at $\mathrm{P}<0.05$

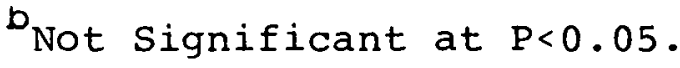

Table 5. Analysis of variance showing the effect of temperature, water velocity, and duration of the experiment on distance traveled by juvenile striped bass $80 \mathrm{~mm}$ long.

\begin{tabular}{lrrr}
\hline Source of Variation & df & MS & F \\
\hline Water Temperature & 5 & $158,121.4$ & $589.5^{\mathrm{a}}$ \\
Water Velocity & 3 & $60,255.6$ & $224.6^{\mathrm{a}}$ \\
Time Swimming & 11 & $6,921.2$ & $23.4^{\mathrm{a}}$ \\
Velocity X Temperature & 15 & $2,320.8$ & $8.7^{\mathrm{a}}$ \\
Velcoity X Time & 33 & 326.1 & $1.2^{\mathrm{b}}$ \\
Time X Temperature & 55 & 250.9 & $0.9^{\mathrm{c}}$ \\
Error & 165 & 268.1 & -- \\
\hline a Significant at $\mathrm{P}<0.001$. & $\mathrm{C}_{\text {Not }}$ significant at $\mathrm{P}<0.05$
\end{tabular}


ORNL-DWG $76-7364$
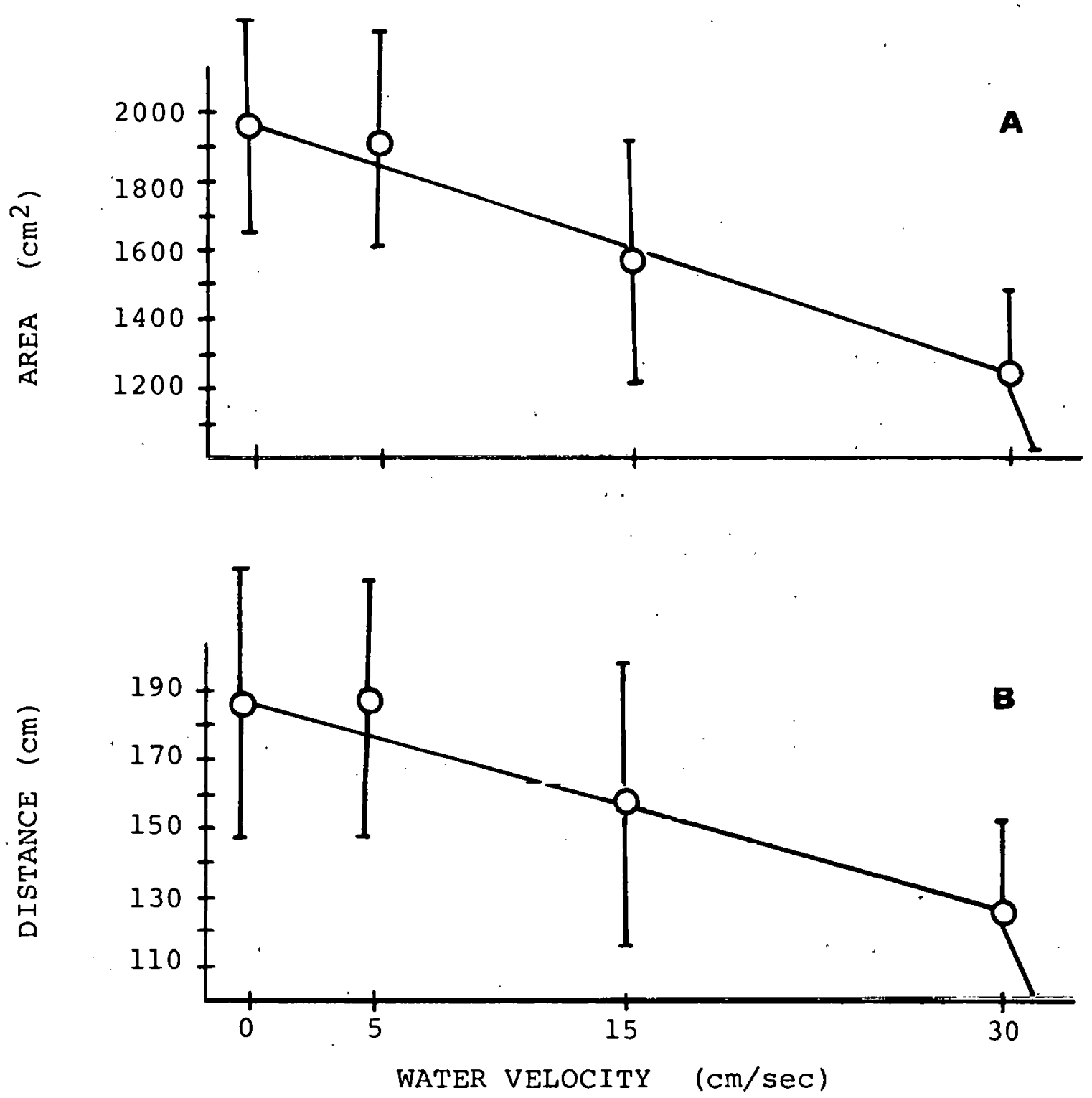

Figure 11. Area ranged (A) and distance traveled (B) by $80 \mathrm{~mm}$ striped bass at four water velocities. Points represent the mean of 72 samples and brackets show one standard deviation. 
of $1968 \mathrm{~cm}^{2}$ at a velocity of $0 \mathrm{~cm} / \mathrm{sec}$ to $127 \mathrm{~cm}$ traveled while ranging a mean area of $1236 \mathrm{~cm}^{2}$ at a velocity of 30 $\mathrm{cm} / \mathrm{sec}$.

Area and distance traveled increased with increasing temperature up to $20 \mathrm{C}$, then declined at higher temperatures (Figure 12 and 13). Both results had a maximal value near $20^{\circ} \mathrm{C}$. Distance traveled and area occupied reached maximal mean values of $231 \mathrm{~cm}$ and $2350 \mathrm{~cm}^{2}$ respectively.

Both area and distance traveled decreased as the length of time the striped bass had been swimming increased (Figure 14). Again the relationship for both measures of activity was similar. During the first $60 \mathrm{~min}$ of an observation juvenile striped bass displayed an exploratory action pattern. Large areas of the test chamber were quickly examined by the test group. Rapid darting motions characterized by abrupt directional change were typical. After 90 min the activity decreased slowly as length of time the fish remained swimming increased. At the end of five hours under all velocities observed, actitivy was noticably reduced. The distances at the 300-min observations ranged from $10 \mathrm{~cm}$ traveled at $5 \mathrm{C}$ to $230 \mathrm{~cm}$ traveled at $25 \mathrm{C}$. Polarized schooling, all individuals having similar orientation and moving synchronously, was fully developed in all $80 \mathrm{~mm}$ striped bass observed. The 10 individuals in each test group generally maintained the same orientation and moved about the test chamber as a unit. At velocities of 15 and $30 \mathrm{~cm} / \mathrm{sec}$ striped bass tended to "line up" in 
ORNL-DWG 76-7363

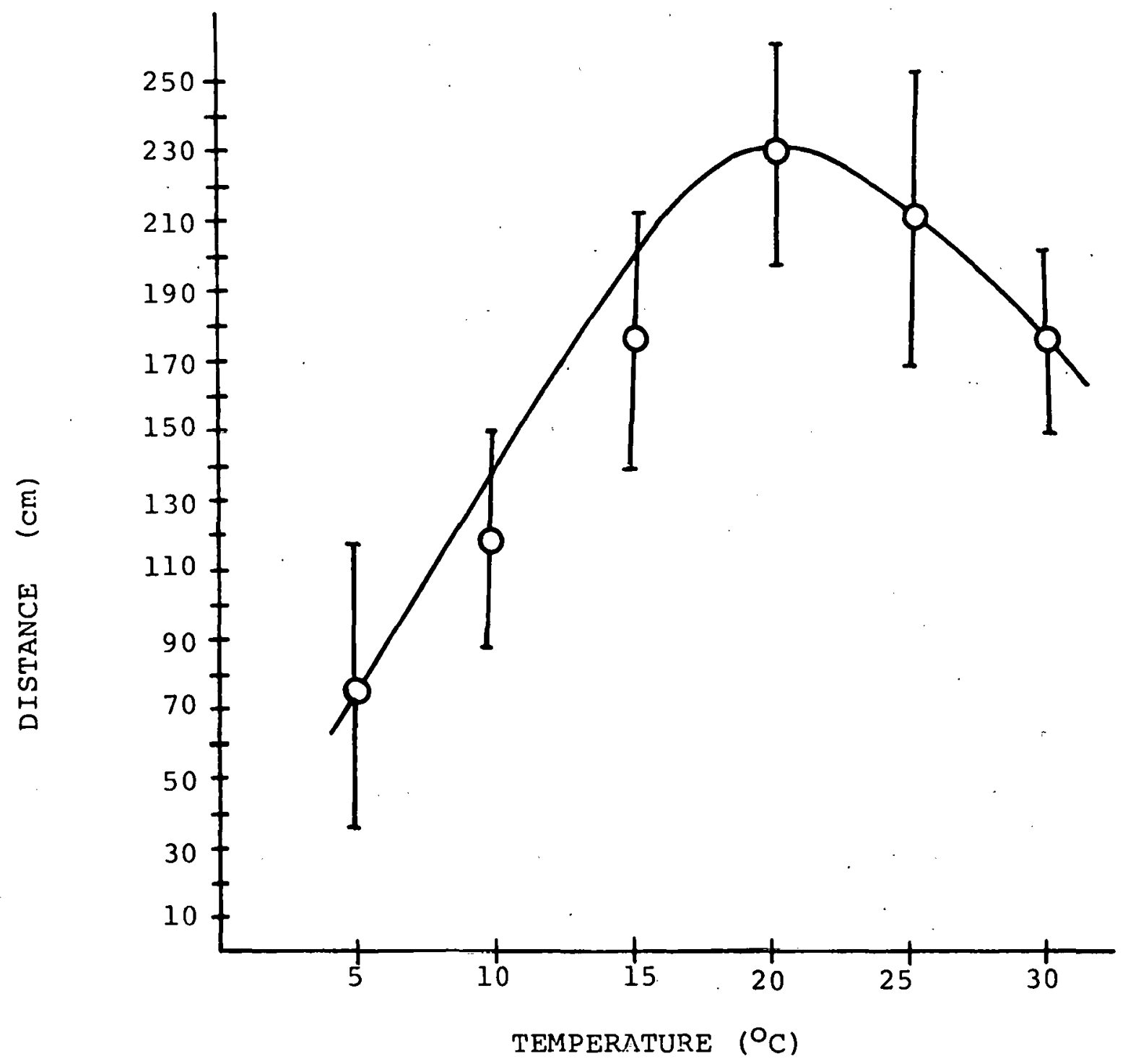

Figure 12. Thermal effects on distance traveled by $80 \mathrm{~mm}$ juvenile striped bass. Curve was fitted by eye. Points represent means of 48 samples and brackets show one standard deviation. 


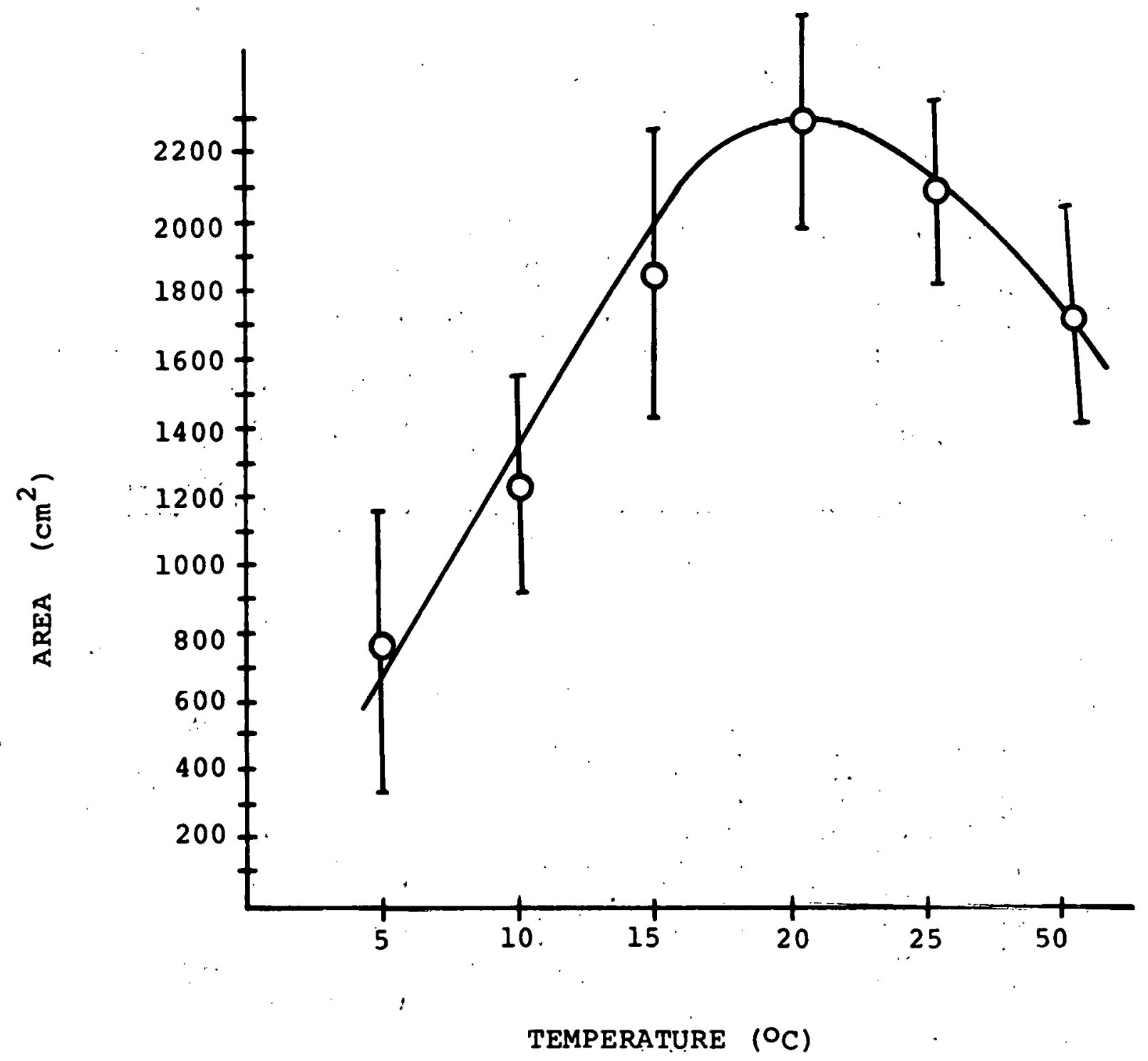

Figure 13. Thermal effects on area ranged by $80 \mathrm{~mm}$ striped bass. Curve was fitted by eye. Points represent means of 40 samples and brackets show one standard deviation. 

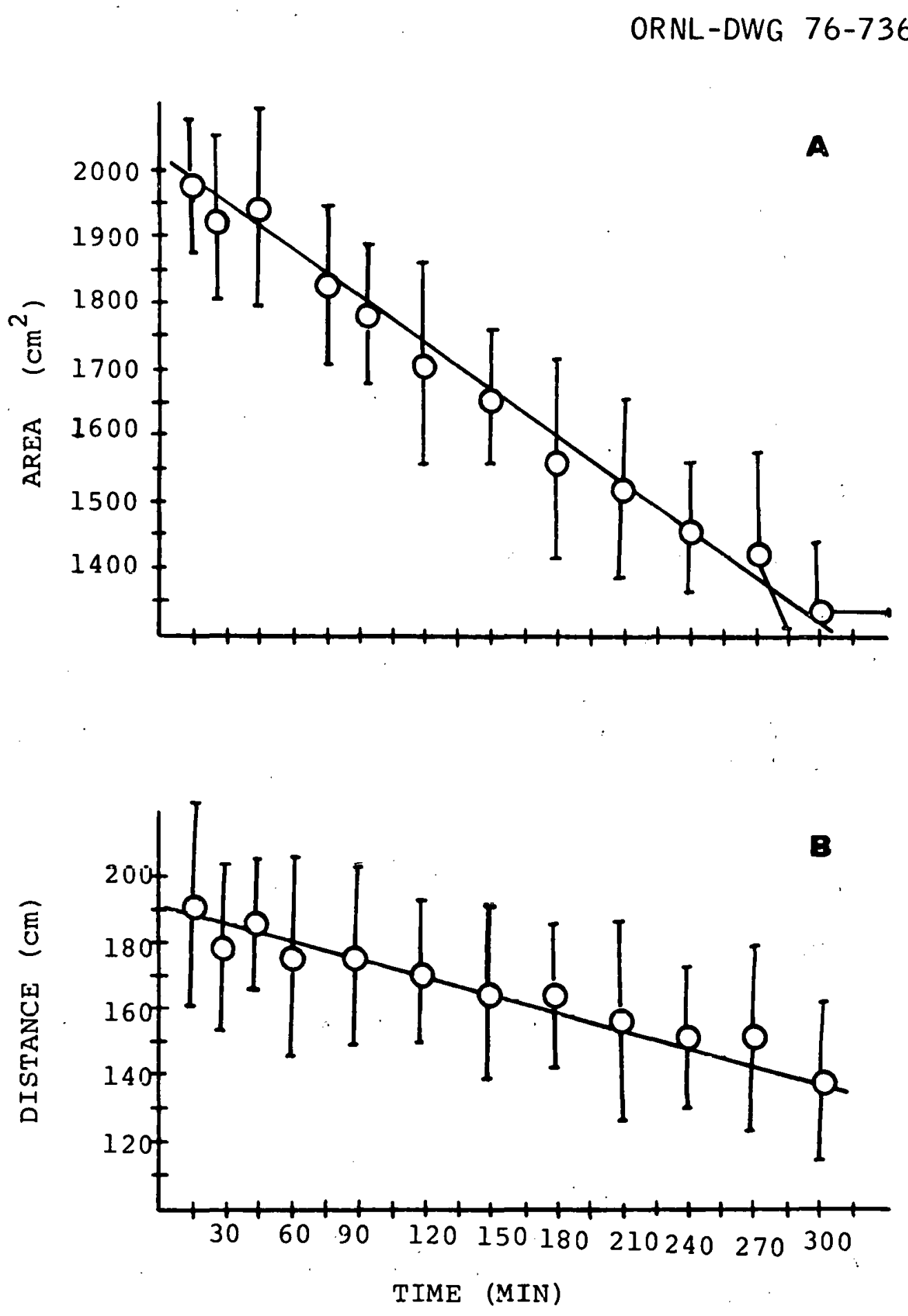

Figure 14. Effects of length of time fish had been swimming on area ranged (A) and distance traveled (B) by $80 \mathrm{~mm}$ juvenile striped bass. Each point represents the mean of 24 samples and brackets show one standard deviation. 
two horizontal rows of five near the upstream screen. Sideto-side spacing in the two rows was very uniform, approximately 3 to $5 \mathrm{~cm}$ between individuals depending on the water velocity. Generally, the two rows were staggered so that juveniles in the back row occupied the space to the rear of and between two juveniles in the front row. Positions in the rows were alternated so no individual occupied the upstream position continuously. Distance between the upstream screen and the fish increased as velocity increased.

Area ranged by blind and sighted fish (Figure 15) at 20.C during 1-min observations differed significantly $(P<0.001)$. At both 15 and $30 \mathrm{~cm} / \mathrm{sec}$ blind fish frequently struck the upstream and downstream screens isolating the test chamber from the remainder of the tank. Generally, the blind fish would locate an area of reduced velocity near the outer wall and remain in that area. Blind striped bass occupied all depths of the water column and most frequently occupied the upper third of the vertical cross-section. Initially, blind juveniles would break the surface of the water. Rapid, uneven swimming with frequent changes in depth and direction characterized activity during the first 30-min. Other sighted juvenile striped bass present in the same test chamber occasionally attempted to school with the blind fish, but these attempts were of short duration. The blind fish never reacted to the presence of conspecifics in the test chamber. At a water velocity of $30 \mathrm{~cm} / \mathrm{sec}$ the blind bass was repeat- 


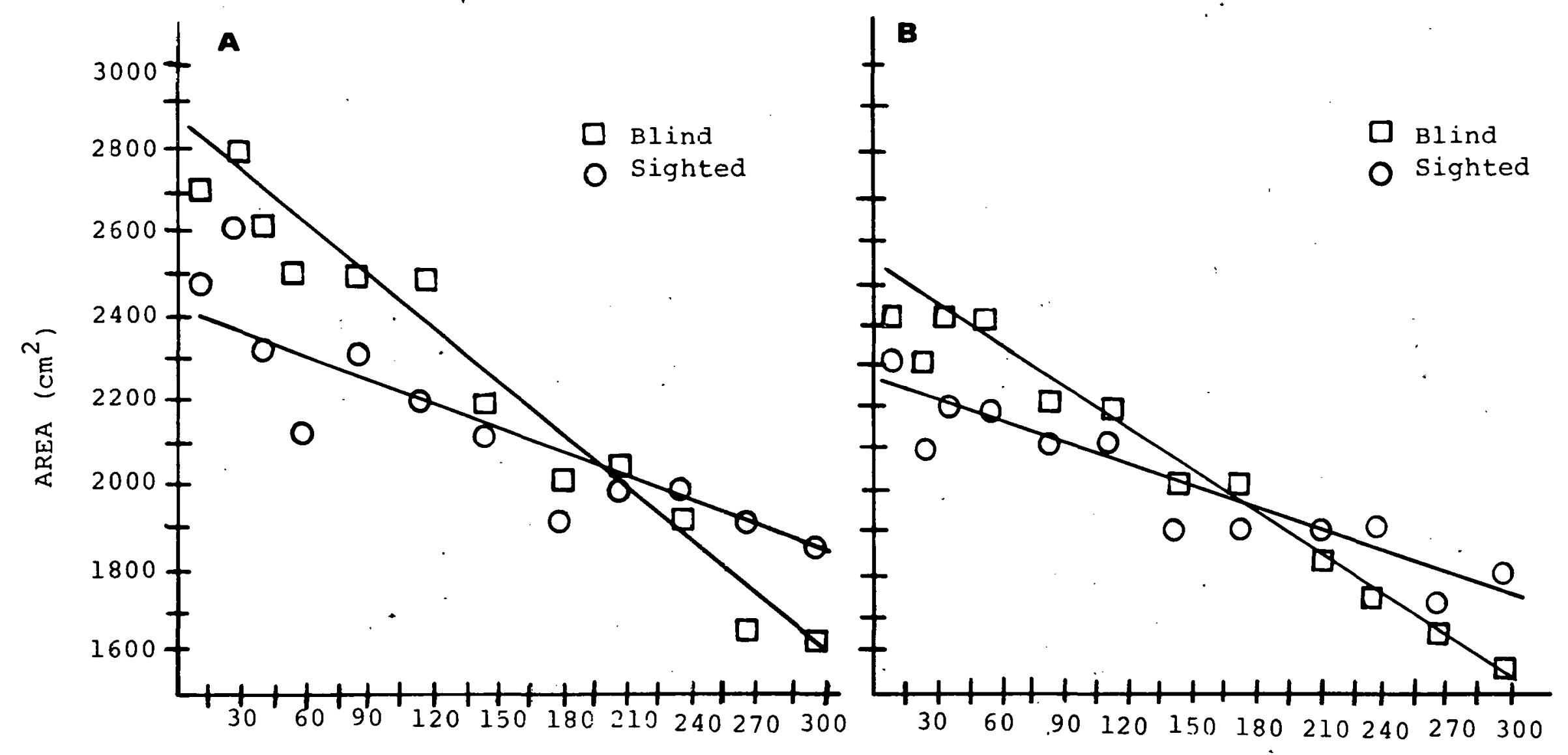

Figure 15. Area ranged by blind and sighted juvenile striped bass during activity periods at $20 \mathrm{C}$ at water velocities of $15 \mathrm{~cm} / \mathrm{sec}$ (A) and $30 \mathrm{~cm} / \mathrm{sec}$ (B). 
edly impinged for a few seconds, but managed to free itself from the screen.

A single large eddy purposely generated in the test chamber increased the area juvenile striped bass ranged at $15 \mathrm{C}$ during one-minute observation periods (Figure 16). The increase in area ranged was greater at a water velocity of $30 \mathrm{~cm} / \mathrm{sec}$ than at a water velocity of $15 \mathrm{~cm} / \mathrm{sec}$. Behavioral observations indicated $80 \mathrm{~mm}$ juvenile striped bass first display an exploratory action pattern when encountering the eddy. Several hours later young bass attempted to swim in the swiftest and least turbulent area of the eddy. At first juveniles traveled with the circular flow of the eddy in an exploratory manner. For several hours, juvenile bass maintained a position in the swiftest portion of the eddy always orienting upstream. Much later, as fatigue increased, the bass again traveled with the circular current. To maintain positive rheotaxis the body of the fish rotated around the central node of the eddy.

Rheotaxis was sensative to changes in water velocity, but not to changes in water temperature. As velocity increased positive rheotaxis increased and lateral rheotaxis. decreased. The relationship between negative rheotaxis and velocity was variable. Temperature had no effect on rheotaxis of juvenile striped bass (Figure 17). 


\section{ORNL-DWG 76-7359}

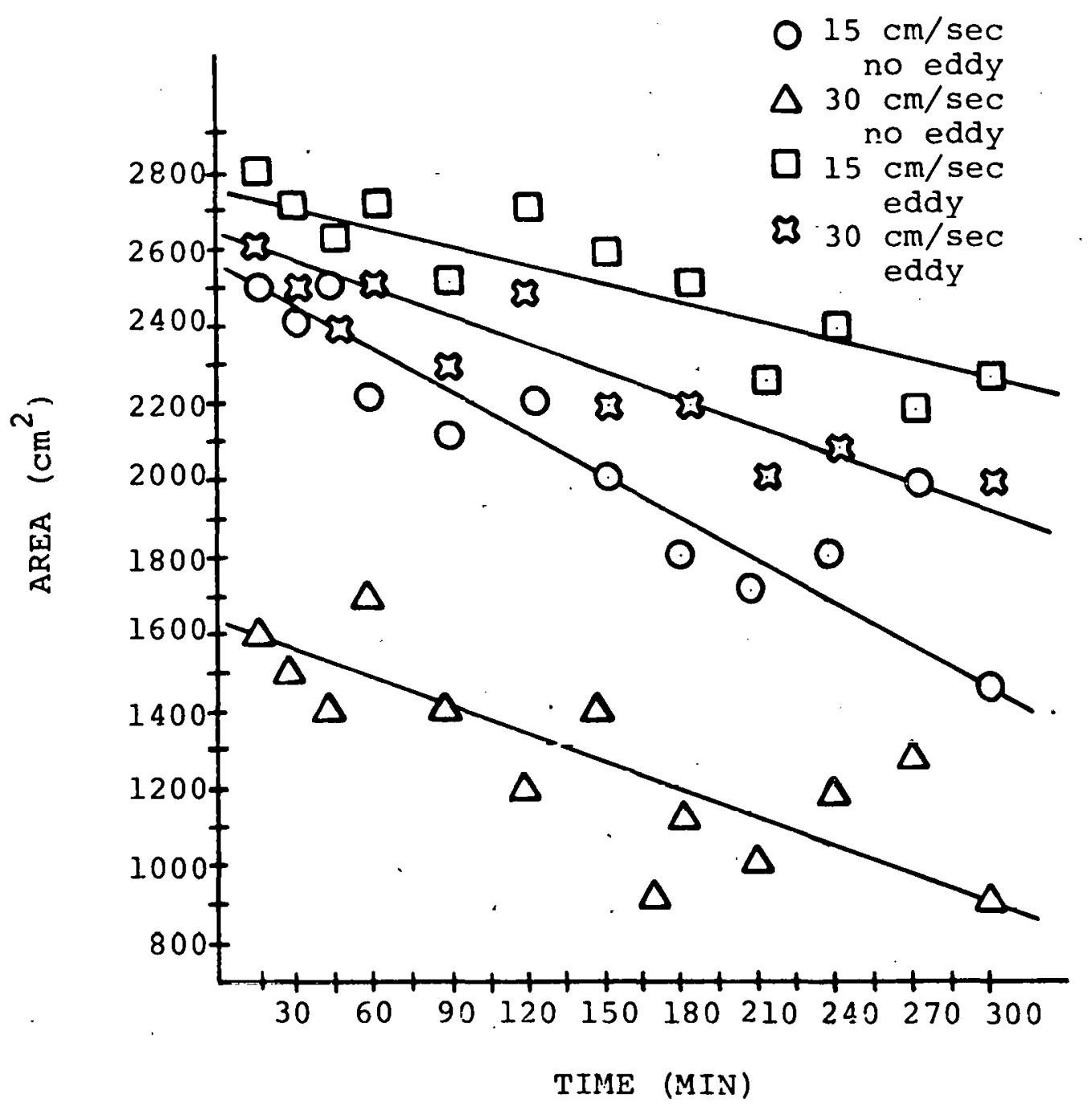

Figure 16.. Area ranged by $80 \mathrm{~mm}$ juvenile striped bass with or without an eddy current at $15 \mathrm{C}$ during 1 -min activity periods. 
ORNL-DWG $76-7358$

\section{TEMPERATURE $\left({ }^{\circ} \mathrm{C}\right)$}

Water

velocity
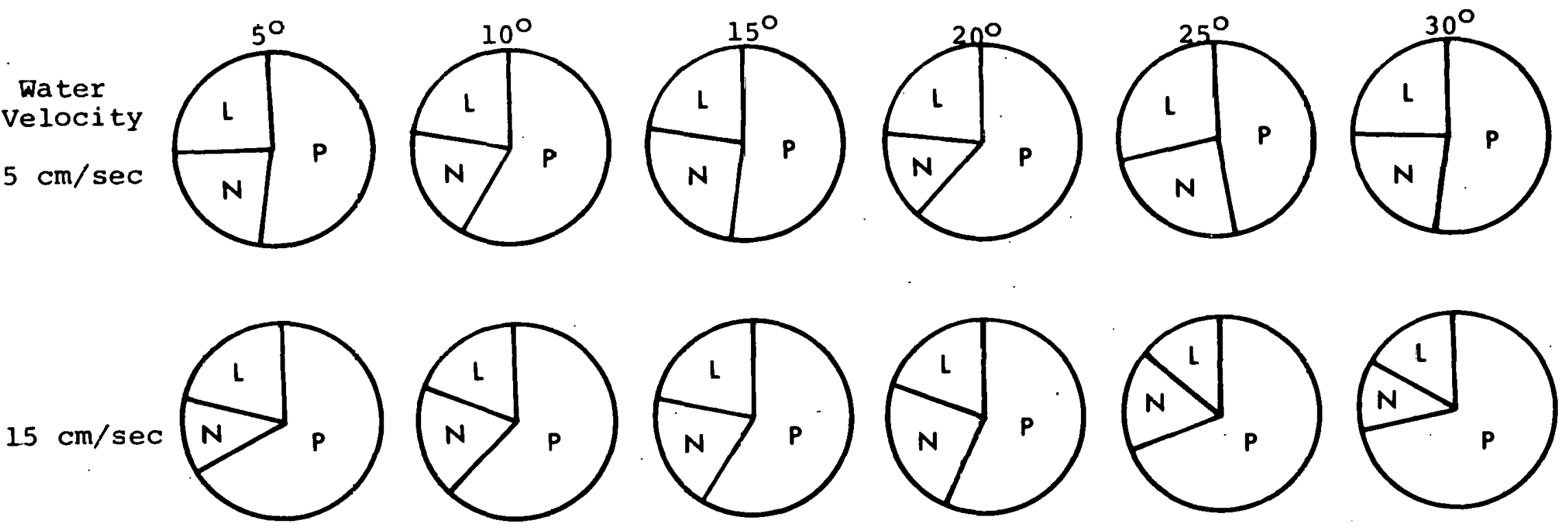

$30 \mathrm{~cm} / \mathrm{sec}$
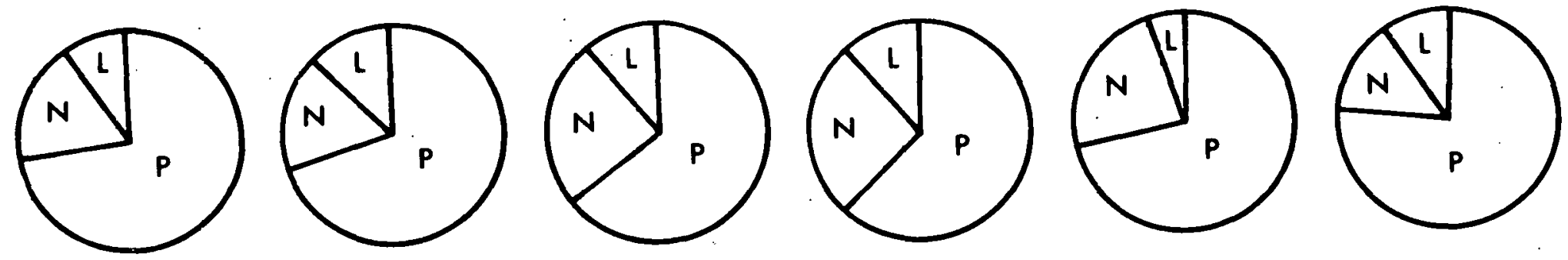

Figure 17. Relationship of rheotaxis at water velocities and temperatures tested. Each circle represents the mean percentage of time fro 36 samples spent in positive (P), negative (N), and lateral (L) rheotaxis during l-min observation periods. 
THIS PAGE

WAS INTENTIONALLY

LEFT BLANK 
CHAPTER VI

\section{DISCUSSION}

Water velocity had a highly significant impact on the area and distance traveled by striped bass 8 to $80 \mathrm{~mm}$ long. As water velocity increased the activity of juvenile I and II bass decreased. In contrast, as the water velocity increased from 0 to $3 \mathrm{~cm} / \mathrm{sec}$ the activity of larval bass increased. Entrainable larval bass demonstrated poor swimming ability, exhibited frequent drift behavior, and remained stationary for minutes occasionally. Juvenile I bass were more active swimmers than larval bass and little time was spent drifting or stationary. All juvenile I striped bass tested at the $27 \mathrm{~cm} / \mathrm{sec}$ water velocity would be susceptible to entrainment because they lack the substantial ability to make forward progress that is necessary to escape a water intake structure. Juvenile II striped bass exhibited a marked increase in swimming ability over younger bass.

The swimming ability and survival of juvenile striped bass observed in these experiments was slightly greater than values perviously reported. Kerr found $100 \%$ survival by striped bass 25 to $75 \mathrm{~mm}$ long tested at $30 \mathrm{~cm} / \mathrm{sec}$ for 10 minutes. Juvenile striped bass 18 to $37 \mathrm{~mm}$ long experienced $80 \%$ endurance under the same experimental conditions. Skinner (1974) found $90 \%$ of striped bass 40 to $50 \mathrm{~mm} 10 \mathrm{ng}$ 
were able to swim at velocities of $24 \mathrm{~cm} / \mathrm{sec}$ for a 6 minute test. period. The results, skinner explained, were lower than values commonly found in the literature due to differences in experimental procedure and pretest handing (juveniles were held in static water). Bibko et al. (1974) found larger striped bass 89 to $138 \mathrm{~mm}$ long maintained a: sustained swim speed of 27 to $60 \mathrm{~cm} / \mathrm{sec}$. Bainbridge (1958) demonstrated exercise did improve swimming performance and juveniles tested in this research were held in acclimation tanks at a maximum water velocity of $3 \mathrm{~cm} / \mathrm{sec}$ for at least a week prior to testing. The length of test chamber acclimation may have also increased the swimming activity of bass reported here. Very little time was allowed by most investigators for recovery from handling and initial exploration. Laurence (1972) allowed $15 \mathrm{~min}$. For the investigations reported in this work a $30 \mathrm{~min}$ acclimation period without current was allowed for each test and such a long acclimation period may have increased swimming activity.

When food was present area and distance traveled by larval striped bass increased. Drift behavior was exhibited as frequently as active swimming in the presence of food, but without food present active swimming occurred even less frequently. When no water flow was present, a condition larval bass rarely face in nature, feeding patterns were the primary source of motion. The reduction in activity when no food was present was dramatic. Several individuals made contact with the observation grid and remained stationary 
in the still water for periods ranging from several seconds to several minutes. In similar feeding studies, Lawrence (1972) observed plankters stimulated larval activity and larvae tested without: food remained on the bottom of the test tank. Juvenile striped bass observed in this study covered less area when food was present. Distance between juvenile I bass was reduced during feeding and visual cueing seemed to play an important part in triggering feeding sequences. Perception of the downstream screen decreased. to the point of repeated tail contact in several groups tested with food present in this investigation.

Low water temperature has frequently been considered. a.major cause of increased winter impingement mortaility (Sonnichsen, et al., 1973; e.g. Bibko, et al.., 1974). Griffith and Tomljanovich (1.975) found a correlation between seasonal low temperature and increased threadfin shad (Dorosoma petenense) impingement at five of twelve power plants surveyed in the southeast. Larval and juvenile I bass in this study were tested at only 20 C, a temperature reflecting encironmental conditions faced in the field during late spring and early summer. Juvenile II bass were tested at temperatures ranging from 5 to 30. C, since young bass could encounter these temperatures during their first fall and winter if growth was slow. of all variables tested, water temperature had the most significant impact on activity. of. $80 \mathrm{~mm}$ striped bass tested in this research. A $30 \%$ reduction in activity occurred between the maximal, $20 \mathrm{C}$ value and the 
lowest temperature tested, 5 C. Similar decreases in swimming ability at low temperature have been demonstrated for juvenile striped bass. Bibko, et al. (1974) demonstrated that juvenile striped bass tested at $4.4 \mathrm{C}$ had lower cruising speeds than those tested at 11.1 C. Tatham (1971) found activity of juvenile striped bass at $25 \mathrm{C}$ was not significant$1 y$ different from activity at 22.2 C. Brett, et al. (1958) showed a $50 \%$ reduction from maximum swimming ability at upper and lower temperature limits for sockeye (ㅇ. nerka) and coho salmon (ㅇ. kisutch).

Duration of the test period had a significant effect on the activity of juvenile II striped bass. A 268 to $32 \%$ reduction of activity was observed in juveniles $80 \mathrm{~mm}$ long after 300 minutes of continuous swimming in this research. Bibko, et al. (1974) observed a $47 \%$ reduction in swim speed of juvenile striped bass after 180 minutes of continuous swimming. A majority of swim speed tests have been of short duration (10 to $30 \mathrm{~min}$ ). Skinner (1974) stated that velocity was more important than length of time fish had been swimming in determining impingement susceptibility. In this study water velocity had a more significant effect on activity of juvenile striped bass than the length of time the fish had been swimming.

Tests of juvenile I and II striped bass conducted in this investigation indicated they are strongly positively rheotactic in water velocities of $15 \mathrm{~cm} / \mathrm{sec}$ or more. Both 
Kerr (1953) and Skinner (1974) observed strong rheotactic response in juvenile striped bass when compared with other fish species. Keenleyside and Hoar (1954) state that failure of positive rheotaxis was the expected result of fatigue in fish exposed to current. In the few impingement sequences observed in this study, juvenile bass swam positively until overcome by velocity and as repeated tail contact with the fixed screen was made orientation with respect to flow decreased. At velocities less than $15 \mathrm{~cm} / \mathrm{sec}$ the rheotactic response was less pronounced in juvenile I and II striped bass. Exploritory movements made during the first $60 \mathrm{~min}$ of an activity period were characterized by equal amounts of positive, negative, and lateral rheotaxis. Rheotaxis, as utilized in this investigation, provided an index of behavioral response to water velocity. Striped bass are a schooling species and schooling behavior may play a significant part in entrainment/impingement. Many of the more susceptible and valuable fish impinged on intake screens are schooling species. Larval and juvenile I striped bass observed in this research did not exhibit fully developed schooling behavior. Juvenile bass 70 to $80 \mathrm{~mm}$ long displayed true polarized schooling. Polarized schooling, as defined by Shaw (1970), occurred when all fish in a group oriented in the same direction and moved as a unit. In schooling fish group interaction is important and two experimente were designed to measure conspecific interaction. The effect of the number of 
individuals present in the test chamber had an impact on swimming activity. Another measure of group interaction was the inter-fish distance between juvenile I striped bass at various velocities. Side-to-side spacing was shown by Cahn (1972) to be important in communication among schooling tuna, Euthynnus affinis. Breder (1965) had a different explination for inter-fish spacing. Vorticies shed from the tails of leading members of a school generate areas of microturbulence and Breder hypothesized that locomotor efficiency was increased when members of a school maintained a certain spacing.

Blind $80 \mathrm{~mm}$ juvenile striped bass introduced into the test chamber with sighted conspecifics demonstrated the inability of such injured fish to escape intake structures. Blind bass were unable to school. Occasionally the sighted bass would school with the blind bass for a few seconds, but the disjointed swimming pattern drove sighted fish away. Once contact was made with the side of the test chamber blind striped bass swam vigorously to maintain a position within the boundary layer, a narrow zone of reduced water velocity adjacent to tank surfaces. Longer exploratory periods displayed by blind bass may have contributed to fatigue. Repeated body contact with the screen weakened blind fish. The behavior of blind striped bass demonstrated the importance of visual cueing in schooling, response to water velocity, and avoidance of the intake screen. 
When a moderately turbulent eddy was generated in the test chamber, juvenile II striped bass covered larger areas than in the absence of the eddy. The greater expenditure of energy may cause juveniles to fatigue more rapidly. Juvenile bass as a group were able to maintain an upstream orientation by rotating about the single node. If more turbulent eddies with multiple nodes were encountered it is likely that fatigue and loss or orientation would occur more rapidly. Kerr (1953) stated that turbulence was hazardous to juvenile fish and intakes should be designed to avoid turbulent areas. 
THIS PAGE

\section{WAS INTENTIONALLY \\ LEFT BLANK}


CHAPTER VII

CONCLUSIONS

After examination of the swimming ability of juvenile striped bass under a variety of test conditions, it is still difficult to define the cause or synergistic causes of cooling water intake-associated fish mortality. Approach velocity does limit swimming activity in proportion to body size. Temperature, particularly low temperature, reduced swimming activity. Awareness of the simulated intake screen decreased when food was present. When the variables above were tested singly and in limited combinations, experimentally induced impingement was low. While behavioral observations of schooling and rheotaxis in the laboratory were informative, the true merit of such techniques remains in their field application where artificial conditions do not distort response.

Information obtained in this study provides many comparisons with swim speed data which often tested only a single variable under pristine experimental conditions. The value of this study is that several variables were tested simultaneously. Inclusion of variables such as the presence of food, turbulence, and injury provide a better estimate of swimming activity under natural conditions. Laboratory testing provides necessary control of variables and evaluation of a technique for field application. 
As in most research, only a few of the many factors affecting swimming activity of juvenile fish could be tested. Future research to determine the effect of the presence of predators, to analyze the results of a sudden drop in temperature, and to determine the effect of turbidity on swimming activity of juvenile fish may provide valuable information on intake-associated biological damage. Preliminary work on the importance visual cueing and the impact of turbulence on activity reported in this study should be continued and expanded. 


\section{BIBLIOGRAPHY}

Alevras, R. A. December 1974. Status of air bubble fish protection system at Indian Point Station on the Hudson River. In Proceedings of the Second Entrainment and Intake Screening Workshop. L.D. Jensen (ed.) Johns Hopkins Univ., 289-291.

Bainbridge, R. 1958. The speed of swimming of fish as related to size and to the frequency and amplitude of the tail beat.' J. Exp. Biol. 35(1): 109-137.

Bainbridge, R. 1964: The problem of excluding fish from water intakes: Proc. Assn. Applied Biol. 53: 505508 .

Bates, D. W. and J. G. Vanderwalker. 1970. Traveling screens for collection of juvenile salmon. In USDI Special Scientific Report - Fisheries No. 608: 1-5.

Beamish, F.W.H. 1964. Respiration of fishes with special emphasis on standard oxygen consumption. III. Influence of oxygen. Canadian J. Zool. 42 (3) : '355366 .

Beamish, F.W.H. 1966. Swimming endurance of some northwest atlantic fishes. J: Fish: Res. Bd." Can: 23(3): 341-347.

Bell, M.C. 1973. Handbook of Design Criteria for Fish Facilities. U.S. Corps of Engineers North Pacific. Division.

Bel1, M.C. 1974. Fish passage through turbines, conduits, and spillway gates. In Proceedings of the second Entrainment and Intake Screening Workshop. L.D. Jensen (ed.). Johns Hopkins Univ. 251-261.

Bibko, P.M., L. Wirtenan; and P.E. Jueser. 1974. Preliminary studies of the effect of air bubbles and intense illumination on the swimming behavior of the striped bass (Morone saxatilis) and the gizzard shad (Dorosoma cepedianum). In Proceedings of the Second Entrainment and Intake Screening Workshop. I.D. Jensen (ed.). Johns Hopkins Univ. 293-304.

Breder, C.M. 1965. Vorticies and fish schools. Zoologica $50: 97-114$. 
Brett, J.M., M. Hollands, and D.F. Alderdice. 1958. The effect of temperature on the crusing speed of young sockeye and coho salmon. J. Fish. Res. Bd. Can. 15: 587-605.

Brett, J.R. 1963. The energy required for swimming by young sockeye compared to drag of a dead fish. Trans. Royal Soc. of Can. 4(1): 441-457.

Brett, J.R. 1965. The swimming energetics of salmon. Sci. Amer. $213(2): 80-85$.

Brett, J.R. 1967. Swimming performance of sockeye salmon (Oncorhynchus nerka) in relation to fatigue time and temperature. J. Fish. Res. Bd. Can. 24(8): 1737-1741.

Brett, J.R. and N.R. Glass. 1973. Metabolic rates and critical swimming speeds of sockeye salmon (Oncorhynchus nerka) in relation to size and temperature.. J. Fish. Res. Bd. Can. 30: 379-387.

Burns, J.W. 1966. Fish screens. In Inland Fisheries Management: A. Calhoun (ed.). California Dept. of Fish and Game. 156-160.

Cahn, P.H. 1972: Sensory factors in the side-to-side spacing and positional orientation of the tuna, Euthynnus affinis, during schooling. Fisheries Bull. 70 (1): 197-204.

Coutant, r.r. 1974. Evaluation of entrainment effect. In Proceedings of the Second Workshop on entrainment and Intake screening. L.D. Jensen (ed.). Johns Hopkins Univ. 1-12.

Dahlberg, M.L., D.L. Shumway and P. Doudoroff. 1968. Influence of dissolved oxygen and carbon dioxide on swimming performance of largemouth bass and coho salmon.' J. Fish. Res. Bd. Can. 25 (1): 49-70.

Downs,' D.I. and K.R. Meddock. 1974. Engineering applications of fish behavior studies in the design of intake systems for coastal generating stations. Paper presented at ASCE National Water Resources Conference. Los Angeles, CA. 1-30.

Eicher, G.J. 1974. Adaptation of hydro fish facilities to steam-electric stations. In Proceedings of the second Entrainment and Intake Wor kshop. L.D. Jensen (ed.). Johns Hopkins Univ. 273-275. 
Fraenkel, G.S. and D.L. Gunn. 1961. The Orientation of Animals. Dover Publications. New York, N.Y.

Fry, F.E.J. 1947. Effects of the environment on animal activity. Univ. of Toronto Stud. Biol., Ser. No. 55, Publ. Ontario Fish Res. Lab. No. 68.

Fry, F.E.J. and J.S. Hart. 1948. Cruising speed of goldfish in relation to water temperature. J. Fish Res. Bd. Can. 7: 169-175.

Goodson, L.F. Jr. 1966. Landlocked striped bass. 'In Inland Fisheries Management. A Calhoun (ed.). California Dept. of Fish and Game. 407-412.

Gray, J. 1937. Psuedorheotropism in fishes. J.., Exp. Biol. $14(1) ; 95-103$.

Griffith, J.S. and D.A. Tomljanovich. 1975. Susceptibility of threadfin shad to impingement. In Proceedings of the Twenty-nineth Annual Conference of Game and Fish Commissions. (In press).

Hocutt, C.H. 1973. Swimming performance of three warmwater fishes exposed to a rapid temperature change. Chesap. Sci. $14(1)$ : 11-16.

Keenleyside; M.H.A. and W.S. Hoar. 1954. Effects of temperature on the response of young salmon to water currents. Behavior. 7(2-3): 77-87.

Kerr, J.E. 1953. Studies on fish preservation at the Contra Costa Steam Plant of the Pacific Gas and Electric Co. California Dept. of Fish and Game, Fish. Bull. No. 92 .

King, L.R. 1970. Preliminary results of swimming speed and endurance studies on white perch and striped bass as determined by the Beamish respirometer. Consolidated Edison Company of New York. Mimeograph.

Landry, A.M. Jr. and K. Strawn. 1974. Number of individuals and injury rates of fishes caught on revolving screens in the P.H. Robinson Generating Station. In Proceedings of the Second Entrainment and Intake Screening Workshop. L.D. Jensen (ed.). Johns Hopkins Univ. 263-271.

Larimore, R.W. and M.J. Duever. 1968. Effects of temperature acclimation on the swimming ability of smallmouth bass fry. Trans. Amer. Fish Soc. $97(2)$ : 175-182.

Laurence, G.C. 1972. Comparative swimming abilities of fed and starved larval largemouth bass (Micropterus salmoides) J. Fish. Biol. 4: 73-78. 
Macleod, J.C. 1967. A new apparatus for measuring maximum swimming speeds of small fish. J. Fish. Res. Bd. Can. $24(6)$ : $1241-1252$.

Mayo, R.D. 1974. Conventional fish screening systems and some promising alternatives. In Proceedings of the Second Workshop on Entrainment and intake Screening. L.D. Jensen (ed.). 277-279 pp.

Prentice, E.F. and F.J. Ossiander. 1974. Fish diversion systems and biological investigation of horizontal traveling screen model VII. In Proceedings of the Second Entrainment and Intake Screening Workshop. L.D. Jensen (ed.). Johns Hopkins Univ. 205-214.

Riesbol, H.S. (Chairman). 1974. Entrapment/impingement: Guide to steam electric power plant cooling system siting, design, and operation for controling damage to aquatic organisms at water intake structures. Amer. National Standard 18.3 Committee. Unpublished Draft.

Schuler, V.J. 1973. Experimental studies in guiding marine fishes of southern California with louvers and screens. Ichthyological Associates. Bulletin 8: 1-39.

Schuler, V.J. and L.E. Larson. 1974. Experimental studies evaluating aspects of fish behavior as parameters in the design of generating station intake systems. Paper presented at ASCE National Water Resource Conference. Lós Angeleś, LA.

Shaw, E. 1970. Schooling in fishes: Critique and review. In Development and Evolution of Behavior. W.H.

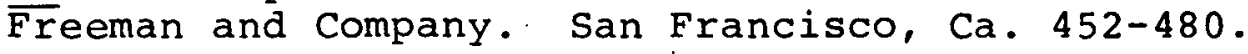

Skinner, J.E. 1974. A functional evaluation of a large louver screen installation and fish facilities research on California water diversion projects. In Proceedings of Second Entrainment and Impingement workshop. L.D. Jensen (ed.). Johns Hopkins Univ. 225-250.

Sonnichsen, J.C. Jr., B.W. Bentley, G.F. Bailey, and R.E. Nakatani. 1973. A review of thermal power plant intake structure designs and realted environmental considerations. Hanford Engr. Devel. Lab. HEDL-TME 73-24.

Stevens, R.E. 1958. The striped bass of the Santee-Cooper Reservoir. Proceedings of the Eleventh Annual Conference of Southeastern Assoc. Game and Fish Commissioners. 253-264. 
Stickney, A.P. 1972. The locomotor activity of juvenile . herring (Clupea harengus harengus L.) in response to changes in illumination. Ecology 53(3): 438-44.4.

Tatham, T.R. 1971. Swimming speed of the white perch, Morone americana, striped bass, Morone saxatilis, and other estuarine fishes. Final report submitted to consolidated Edison Co. of New York. Ichthyological Associates. Unpublished manuscript.

Todd, J.H., D. Engstrom, S. Jacobson, and W.O. McLarney. 1972. An introduction to environmental ethology: A preliminary comparison of sublethal thermal and oil stresses on the social behavior of lobsters and fishes from a freshwater and marine ecosystem. Unpublished Manuscript.

U.S. Code. Vol. XXXIII, Sec. 316(b). 1972. Federal Water Pollution Control Act Amendments.

U.S. Environmental Protection Agency. 1973a. Development Document for Proposed Best Echnology Available for Minimizing Adverse Environmental Impact of Cooling Water Intake Structures. EPA 440/1-74/015.

U.S. Environmental Protection Agency. 1973b. Reviewing Environmental Impact Statements - Power Plant Cooling Systems, Engineering Aspects. EPA 660/2-73/016.

Weight, R.H. 1958. Ocean cooling water system for $800 \mathrm{MW}$ power station. J. Amer. Soc. Civil Engr. Power Div. Paper 1888, 1-23. 
THIS PAGE

\section{WAS INTENTIONALLY \\ LEFT BLANK}


ORNL/TM $=5368$

\section{INTERNAL DISTRIBUTION}

1. S. M. Adams

2-11. S. I. Auerbach

12. B. G. Blaylock

13-32. R. R. Bowles

33. R. W. Brocksen

34. S. W. Christensen

35-63. C. C. Coutant

64. D. K. Cox

65. Patricia Cunningham

66. L. L. Dye

67. J. W. Elwood

68. L. D. Eyman

69. C. W. Gehrs

70. J. S. Griffith

71. S. E. Herbes
72. S. G. Hildebrand

73. J. S. Mattice

74. R. B. McLean

75. Herman Postma

76. D. E. Reichle

77. C. R. Richmond

78. E. G. Struxness

79. J. S. Suffern

80. W. Van Winkle

81. H. E. Zittel

82. Biology Library

83-84. Central Research Library

85-86. Laboratory Records Dept.

87. Laboratory Records, ORNL-RC

88. ORNL Patent Office

89. ORNL Y-12 Technical Library

\section{EXTERNAL DISTRIBUTION}

90. Research and Technical Support Division, ERDA-ORO.

91. William Brungs, Environmental Research Laboratory, U. S. Environmental Protection Agency, Duluth, MN 55806.

92. Jared Davis, Nuclear Regulatory Commission, Washington, DC 20555.

93. David A. Etnier, University of Tennessee, Knoxville, TN 37916.

94. R. A. Goldstein, Electric Power Research Institute, Palo Alto, CA 94303.

95. C. P. Goodyear, Power Plant Team, U.S. Fish and Wildlife Service, Ann Arbor, MI 46106.

96. Gordon Hall, Tennessee Valley Authority, Norris, TN 37828.

97. Heyward Hamilton, Division of Biomedical and Environmental Research, ERDA, Washington, DC 20545.

98. Roger A. Minear, Untversity of Tennessee, Knoxville, TN 37916.

99. C. Osterberg, Division of Biomedical and Environmental Reseärch, ERDA, Washington, DC 20545.

100. Clyde Voightlander, Tennessee Valley Authority, Norris, TN 37828. 101-127. Technical Information Center, Oak Ridge, TN 37830. 